\title{
The morphology and morphodynamics of sand-gravel subaquatic dunes: the Raba River estuary, Poland
}

\author{
Artur RADECKI-PAWLIK ${ }^{1 *}$ and Leszek KSIAZŻEK ${ }^{1}$ \\ ${ }^{1}$ Department of Hydraulic Engineering and Geotechnics, University of Agriculture in Krakow, al. \\ Mickiewicza 24-28, 30-059 Krakow, Poland
}

* Correspondence to: Artur Radecki-Pawlik, University of Agriculture, Poland. E-mail: rmradeck@cyf-kr.edu.pl

(C2012 University of Suceava and GeoConcept. All rights reserved doi: 10.4316/GEOREVIEW.2012.21.1.52

\section{GEOREVIEW}

Article history

Received: August 2012

Received in revised form:

October 2012

Accepted: November 2012

Available online: January

2013
ABSTRACT: In the outlet of the Raba River to the Vistula, the biggest river in Poland, the morphology and morphodynamics of sand and finegravel subaquatic dunes were investigated. The site is situated in highland region just about the entrance to Polish Carpathians. The dunes formed on the Raba River bed estuary are composed of sand and fine gravel ( $d_{50}$ up to $11 \mathrm{~mm}$ ). Systematic observation (within the 2000-2005) were made of geometry, sediment composition and hydraulic climate under which the dunes grew and decomposed. The investigation focuses here mostly on the geometrical parameters of these bed forms such as height, length, as well as granulometric characteristics of the sediment. Based on in-site measurements different hydraulic parameters were calculated such as shear stresses, resistant coefficient, Froude and Reynolds numbers and roughness coefficient. It was found that the relation between height $(H)$ and length $(L)$ of the Raba estuary dunes describes the formula: $\mathrm{H}=0.05 \mathrm{~L} 0.35$. Also these dunes are steeper and flatter then classical $H / L$ index is: $H / L=0.0518 L 0.622$. During the field campaign, when the foot access to the estuary was possible and dunes were spotted on the river bed the range of measured water velocity was from $v=0.39 \mathrm{~m} \cdot \mathrm{s}^{-1}$ to $v=0.81 \mathrm{~m} \cdot \mathrm{s}^{-1}$ with the highest velocity over the dune crest. At the same time the measured range of shear stresses within the dune field formation were from $\tau=0.115 \mathrm{~N} \cdot \mathrm{m}^{-2}$ to $\tau=1.59$ $\mathrm{N} \cdot \mathrm{m}^{-2}$. On the field investigations the CCHE2D - two-dimensional unsteady flow and sediment transport model for non-equilibrium transport of non-uniform sediment mixtures - was applied. The model was used to simulate the morphodynamic changes along the outlet of the Raba River basing on field observations of the 2005 summer flood as well as calculate hydraulics parameters. It was also used to test and confirm the range of morphodynamic changes, which take place along the research reach where the dunes are being developed. The maximum water flow velocity for and the shear stresses for the summer flood caused the hydrodynamic conditions when water velocity as well as shear stresses values reached respectively up to $\mathrm{v}=1,93 \mathrm{~m} \cdot \mathrm{s}^{-1}$, and $\tau=$ $19.74 \mathrm{~N} \cdot \mathrm{m}^{-2}$ which shows that critical conditions of bed load movement were exceeded for the Raba estuary.

KEY WORDS: sand-gravel dunes, estuary zone, morphodynamics, the Raba River 


\section{Introduction}

Sand-gravel subaquatic dunes studies are very rare, especially those involving field measurements. There are a number of reasons why: field campaigns are time consuming, expensive, need quite often floating vessels like ships or boats, need many people but most of all the sand-gravel dunes are needed to be found and studied which is extremely difficult to achieve. Especially, the most comfortable situation one can meet is when the foot access to the place with sand-gravel dunes is possible, since it allows studying them nearly unspotted still visible and fruitful for science information.

Why one might be interested in sand-gravel subaquatic dunes formation and studies? The number of respects must be listed when talking about the research of them. Firstly, the fact that sand-gravel dunes are extremely rare in subaquatic environment, secondly, an appreciation of the changes of river bed morphology, thirdly, the dunes are responsible for flow resistance, which is significant, for ex-ample, when designing hydraulics structures or calculating flow residence times for water supply or pollutant dispersion. Next, understanding the bed form shaping process is important for geologists to interpret how sedimentary rocks were deposited, where ancient sedimentary assemblages are believed to be of alluvial origin. Finally, because of the need for a better understanding of the process of their formation. Within the lights of above statements the authors were lucky to find in the field sand-gravel subaquatic dunes with foot access for study, which were situated at the outlet of the highland character of the Polish Carpathian river the Raba.

Gravel subaqueous bed forms are those with a median grain size greater then $2 \mathrm{~mm}$. Along the worldwide literature there is few information on the hydrodynamic development of such gravel features. Equilibrium and non-equilibrium gravel dunes range in length from less then $0.6 \mathrm{~m}$ to greater then $100 \mathrm{~m}$. Their heights range from less then $0.1 \mathrm{~m}$ to $16 \mathrm{~m}$ (Carling, 1999; RadeckiPawlik et al., 2006). In general terms dunes have lengths that scale primarily with boundary layer thickness or water depth (Best, 1996). Height (H) and length (L) data for the gravel dunes reported by some researchers (Carling, 1999) are consistent with the $\mathrm{H} / \mathrm{L}$ function reported by Ashley (1990) for equilibrium dunes developed in sand. Using Ashley's dune form criteria of height $(>0.1 \mathrm{~m})$ and length $(>0.6 \mathrm{~m})$ as a general guide it can be shown that gravel dunes have been correctly identified in the number of studies (Galay, 1967; Dinehart, 1989; Carling, 2005). As far as gravel bed forms hydrodynamics is concerned, gravel dunes are supposed to develop for a range of Froude numbers up to 0.75 . For the non-dimensional mean shear stress $\theta=0.25$ they should reach their maximum height and start to reduce in height at Shields parameter value $\theta=$ 0.30 (Carling, 1999). The other bed forms, which develop on the river bed are ripples. Their length is proportional to the grain size. They have heights up to a few tens of millimeters and lengths less then $0.6 \mathrm{~m}$ (Allen, 1984). The reports from the literature about ripples that are developed in gravel are controvertible, being based mostly on length/height criteria. However, ripples are supposed to develop only in the bed sediments not coarser than about $0.6 \mathrm{~mm}\left(\mathrm{~d}_{50}<\right.$ $0.6 \mathrm{~mm})$ in hydraulic smooth flow $(\mathrm{v} * \mathrm{D}<10)$ which is not associated with mobile gravel. Though Gomez (1989) reported some gravel bed forms, which he called ripples, but Carling (1999) suggests that they were bed load sheets. Finally some scientists (Kuhnle, 1986; Iseya and Ikeda, 1987) report bed load sheets and define them as low-relief bed forms, that develop in mixture of 
coarse sand and gravel ( $\mathrm{d} 50$ from $2 \mathrm{~mm}$ to $5 \mathrm{~mm}$ ). These features are one or two grains in height and share some characteristic of incipient dunes (Bridge, 1993). What is worthy of notice is that no bed load sheets developed in $100 \%$ gravels in experiments described by Iseya and Ikeda (1987) as well as Dietrich et al. (1989). At the same time in a mixture of gravel and sand, (Whiting et al., 1974) describes bed sheets as stable bed forms, which could grow in thickness giving asymmetric dune like forms up to $0.10 \mathrm{~m}$ height, and that such bed forms give the bed instability from which incipient dunes can develop.

The paper presented here examines the changes of hydrodynamic conditions such as: river channel morphology, water velocity, shear stress, sediment transport rate and sediment size along the outlet section of the sand-gravel upland river in Polish Carpathians. The first objective of the presented work is to better understand how riverbed forms developed in the mixture of sand and gravel. The second, to help listed above fields such as river engineering and geology when one considers river bed data for many purposes professional analysis. Next, the rarity of existing such features in nature is enough sufficient reason to pay attention to them. Consequently, this paper addresses the bulk flow dynamics and the granulometric composition of subaquatic river sand-gravel dunes where all data where collected within field campaigns between 2001 and 2006. On the top of field measurements during field works, along the paper, a CCHE2D two-dimensional unsteady flow and sediment transport model for non-equilibrium transport of non-uniform sediment mixtures was applied to better understand and predict morphological changes of the river bed covered periodically with dunes. The model was used to simulate the hydrodynamic changes basing on field observations of one 2005 summer flood and to test and confirm the range of morphodynamic changes, which take place along the research reach where the dunes are being developed. The study site was placed in the upland part of the Raba River below the Dobczyce Water Reservoir and close to the confluence with the Vistula River.

\subsection{Study location}

The Raba River (137 km long with a catchment area of $1537 \mathrm{~km} 2$ ) is mostly (86\%) situated in the Polish part of the Eastern Carpathian Mountains (the Wyspowy Beskid and the Zywiecki Beskid) which are Carpathian flysh [Radecki-Pawlik et al. 2006, Słowik-Opoka 2006] - Fig.1. Its streambed, along the alluvial part, consists mostly of sandstone and mudstone bed-load pebbles and cobbles (from Magurian nappe). The typical structure of the lower Raba River alluvial plain, from the beginning of the 20th century consists of normally loose pebble gravels, open work pebble gravels, dilated framework pebble gravels, trough cross-stratified and parallel laminated medium to very coarse grained sands, massive find sands and muds [Wyzga 1992]. The coarser grains, which collect as armor on the river bed, also form a framework, the interstices of which are filled by a matrix of finer sediment. The Raba River, during the spring and early summer floods, experiences frequent bed load movement, which is reflected in many mobile gravel bars, which form along the margins and centre of the river channel. The research region of the Raba River - $700 \mathrm{~m}$ long, close to the Uście Solne municipality, where the Raba joins the Vistula River, is situated at the border of the uplands ( $14 \%$ of the catchment is situated in Carpathian intramontane and submontane depressions). The river loses here its mountainous character and is alluvial. The river bed sediment here is the mixture of sand and gravel. The river bed usually is characterized by an armor layer where the range of sediment is from $0.4 \mathrm{~mm}$ do $50 \mathrm{~mm}$, with sand and gravel moving above it - Photo 1 . In low to medium flows the water is very clear making the sediment transport processes visible to the eye. 


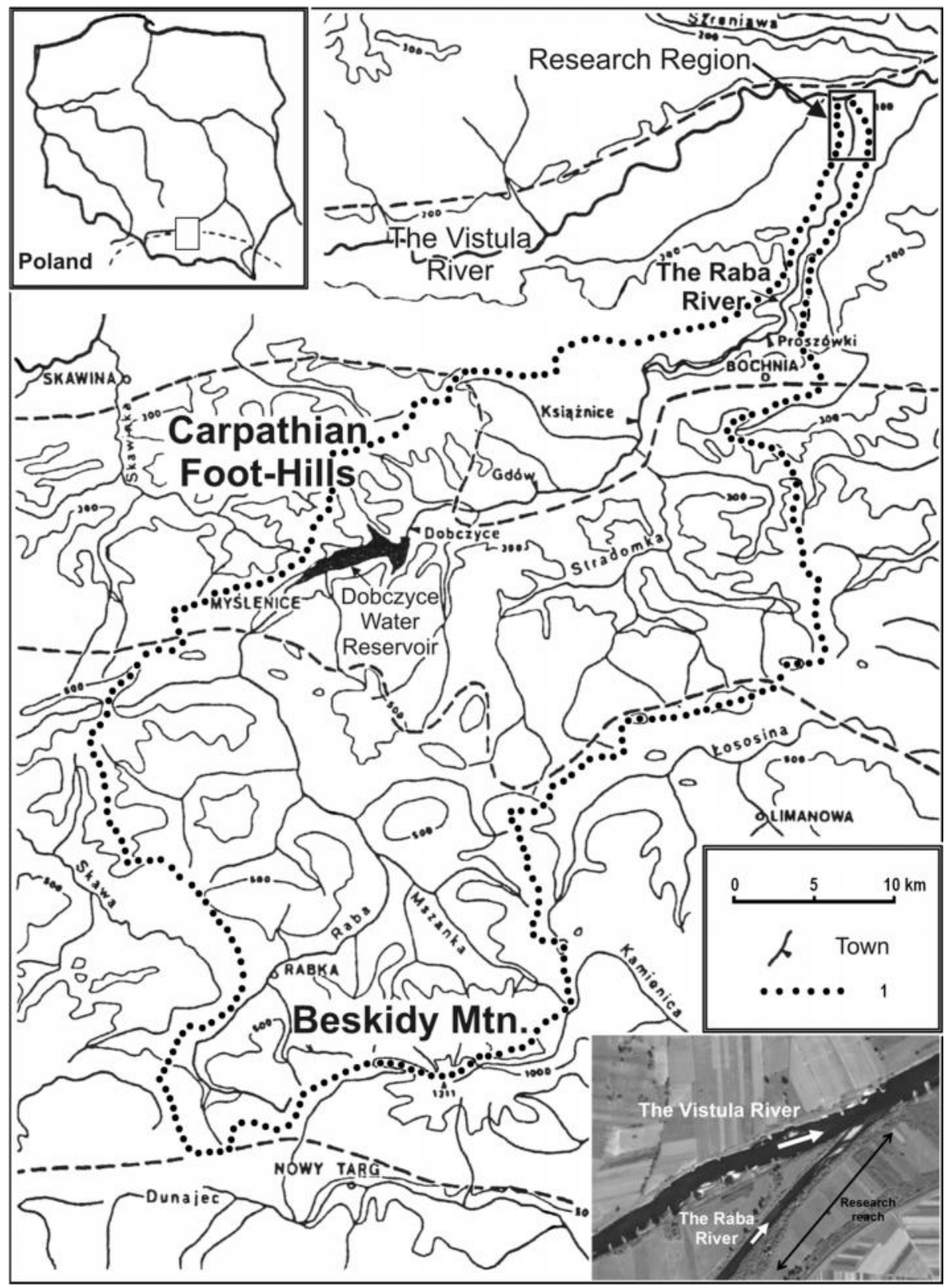

Figure 1. Map and air photography showing the research region - the Raba River estuary, 1 watershed borders

On the armoring layer sand and sand-gravel bedforms appear under certain range of hydraulics conditions. These bedforms are built up with sediment of the range from $d_{50}=0.5 \mathrm{~mm}$ up to 11 $\mathrm{mm}$. The average slope of the whole Raba River is 0.0044 , the slope of the whole lower part of the Raba is 0.0020 whereas the slope of the research reach, at the confluence, is 0.0006 . According to Krzanowski [1972] the average annual flow is here $20.86 \mathrm{~m}^{3} \cdot \mathrm{s}^{-1}$ and the minimum annual flow is $2.71 \mathrm{~m}^{3} \cdot \mathrm{s}^{-1}-$ Tab.1. 
Table 1. Physical characteristics of investigated river

\begin{tabular}{lc}
\hline Variables & The Raba River \\
\hline Precipitation $[\mathrm{mm}]$ & 760 \\
Catchment Area $\left[\mathrm{km}{ }^{2}\right]$ & 1573 \\
Channel Length $[\mathrm{km}]$ & 137 \\
Mean annual flow $\left[\mathrm{m}^{3} \cdot \mathrm{s}^{-1}\right]$ & 20.86 \\
Minimal annual flow $\left[\mathrm{m}^{3} \cdot \mathrm{s}^{-1}\right]$ & 2.71 \\
Average slope $[-]$ & 0.0044 \\
Average slope of the research region $[-]$ & 0.0006 \\
Two years flood Q50\% $\left[\mathrm{m}^{3} \cdot \mathrm{s}^{-1}\right]$ & 498 \\
Ten years flood Q10\% $\left[\mathrm{m}^{3} \cdot \mathrm{s}^{-1}\right]$ & 1007 \\
One hundred years flood Q1\% $\left[\mathrm{m}^{3} \cdot \mathrm{s}^{-1}\right]$ & 1724
\end{tabular}

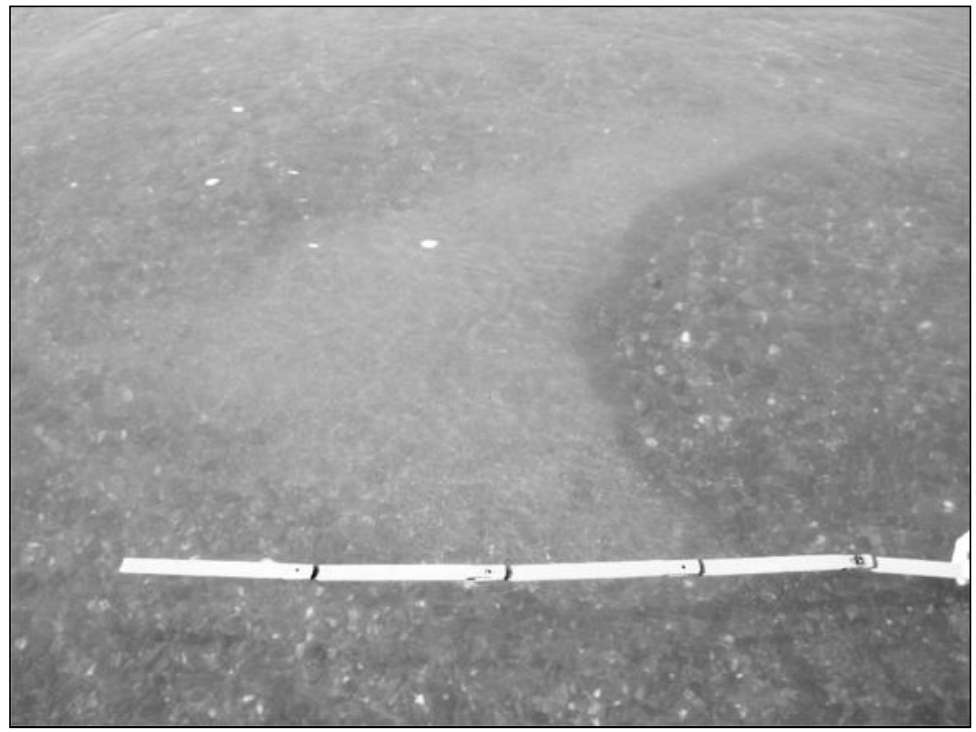

Photo 1. A typical parabolic type of sand-gravel dune from the bed of the Raba River outlet - flow direction is from the right to the left (photo by A. Radecki-Pawlik).

\section{Methods}

\subsection{Morphometric and hydrodynamic data}

The research location was safely accessible on foot from the Raba River banks under low discharge and in a rubber boat under mean discharge conditions. The location was being visited daily during several sampling periods between 2001 and 2005. The work within the research reach concentrated on surveying the migration of several ripples, dunes and other sand and sand-gravel structures, measuring the water depth $D$, dune length $L$, dune height $H$ and the speed of the flow $V$ with a NAUTILUS 2000 magnetic current meter. Velocities of running water were recorded above all characteristic points of the bed-forms: crest, trough, along the stoss and lee slopes and finally above the flat bed. Having velocities profiles in all characteristic dunes points, hydrodynamic parameters listed below, responsible for morphodynamic changes, could be calculated. 
The knowledge of shear stresses value is crucial when talking about sand-gravel grains movement, which is directly connected, with subaquatic dunes formation. After analyzing hydrodynamic forces, one can calculate the Shields parameter known also as non-dimensional shear stresses $\theta$ [Allen 1968]:

$\theta=\frac{\tau_{c r}}{\left(\gamma_{s}-\gamma\right) d}=\frac{\tau_{c r}}{\left(\rho_{s}-\rho\right) g d}=\frac{h J \rho}{d\left(\rho_{s}-\rho\right)}$

This parameter shows the dependence of the drag force on the grain weight. Introducing the shear velocity $\mathrm{v}^{*}$ the equation (1) can be presented:

$$
\frac{\tau_{c r}}{\left(\gamma_{s}-\gamma\right) d}=\frac{v_{*}^{2} \rho}{\left(\rho_{s}-\rho\right) g d}=\frac{v_{*}^{2}}{(s-1) g d}=\theta
$$

where: $\tau_{c r}$ is the critical shear stresses responsible for movement of grains, $\rho$ - sediment and water density $\left[\mathrm{kg} \cdot \mathrm{m}^{-3}\right], \mathrm{g}$ - gravity acceleration $\left[\mathrm{m} \cdot \mathrm{s}^{-2}\right], \mathrm{h}-$ water depth $[\mathrm{m}], \mathrm{J}-$ slope of energy line $[-], d-$ grain size $[\mathrm{m}], \tau-$ shear stresses $\left[\mathrm{N} \cdot \mathrm{m}^{2}\right]$.

In that way described the Shields parameter is the basic non-dimensional shear stresses value responsible for a movement of individual grain sizes when excited.

Next the Froude'a number was calculated from the equation $\mathrm{Fr}=\mathrm{v}^{2} / \mathrm{g} \mathrm{h}$ and the Reynolds number $\operatorname{Re}=\mathrm{v} \mathrm{h} / \mathrm{v}$ where: $\mathrm{v}-$ average water flow $\left[\mathrm{m} \cdot \mathrm{s}^{1}{ }^{1}\right], v-$ kinematic fluid viscosity.

To calculate various flow resistance coefficients, the methods given by [Wijbenga 1990, Przedwojski et al. 1995] were used. The Darcy-Weisbach flow resistance coefficient was obtained from

$f=8 \mathrm{gJ} R / \mathrm{v}^{2}=8\left(\mathrm{v}_{*} / \mathrm{v}\right)^{2}$

where: $v$ - average cross-section velocity $\left[\mathrm{m} \mathrm{s}^{-1}\right]$.

All necessary water velocity measurements were based on [Jarrett 1990] recommendations regarding the taking of velocity profiles in river cross-sections. Bergeron and Abraham's [1992] methods were then applied to the field data, and shear velocity $v_{*}$ values were calculated from the velocity profiles obtained near to the riverbed. Finally, shear stress $\tau$ values were calculated from: $\tau=v_{*}^{2} \cdot \rho\left[N \cdot m^{-2}\right]$.

\subsection{Sediment composition of dunes}

For sediment sampling many techniques were used in the field depend on the access to the dunes body. First of all, the technique described by Church [1987] was applied. Samples were collected from a homogeneous body of sub-armour sediment, so as not to combine them with the distinct surface material. Then the sieving analysis for coarse grains was carried out by hand in the field using round-mesh sieves. Fine material was sieved in the laboratory. Secondary, to study in detail the bed form composition, the sample freezing method was applied. 


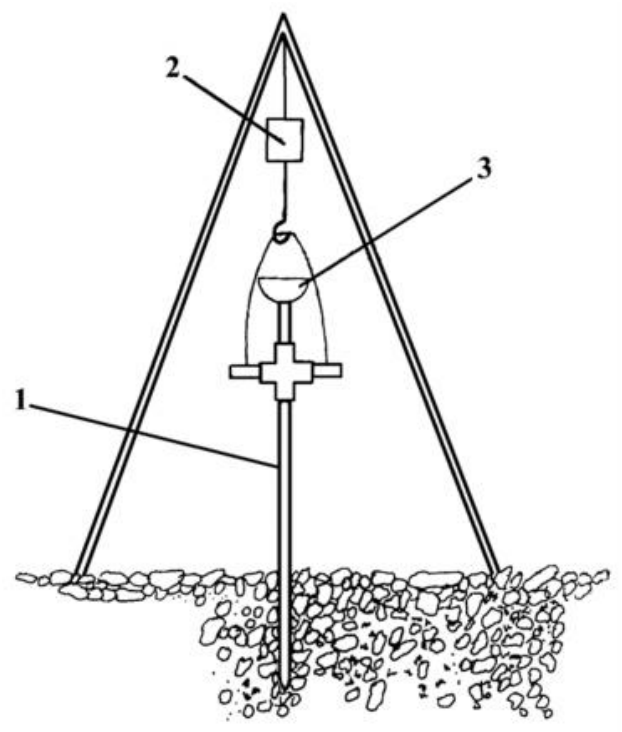

Figure. 2. Freeze sampler 1 - copper tube, $\varnothing=5 \mathrm{~cm}, 2$ - hoist holder, 3 - funnel [Michalik et al. 1996]

Here a bedload sample from the river bed is frozen by means of a probe, supplied with liquid nitrogen and driven into the bed (Fig. 2). In the method, a copper tube (1), $\varnothing=5 \mathrm{~cm}$ is driven into the river bed at a depth of $30-50 \mathrm{~cm}$. The tube is ended with a cross with a hoist holder (2) and an inlet bowl. Liquid nitrogen is poured through a funnel (3) into the probe. The freezing time depends mainly upon the water temperature, debris consolidation degree and the debris grain size. Fast cooling down of the tube freezes the surrounding bed material [Carling and Crompton 1988].

A frozen sample is taken out with a hand hoist and placed on a special box. The box is provided with baffles, for example at $5 \mathrm{~cm}$ intervals, so that the material under de-freezing may fall in the opposite layer. For each layer one can determine the grain-size distribution. The application of the bedload sample freezing method makes possible the recognition of the structure in the river bed, i.e. determination either the armouring layer and the bed/substratum.

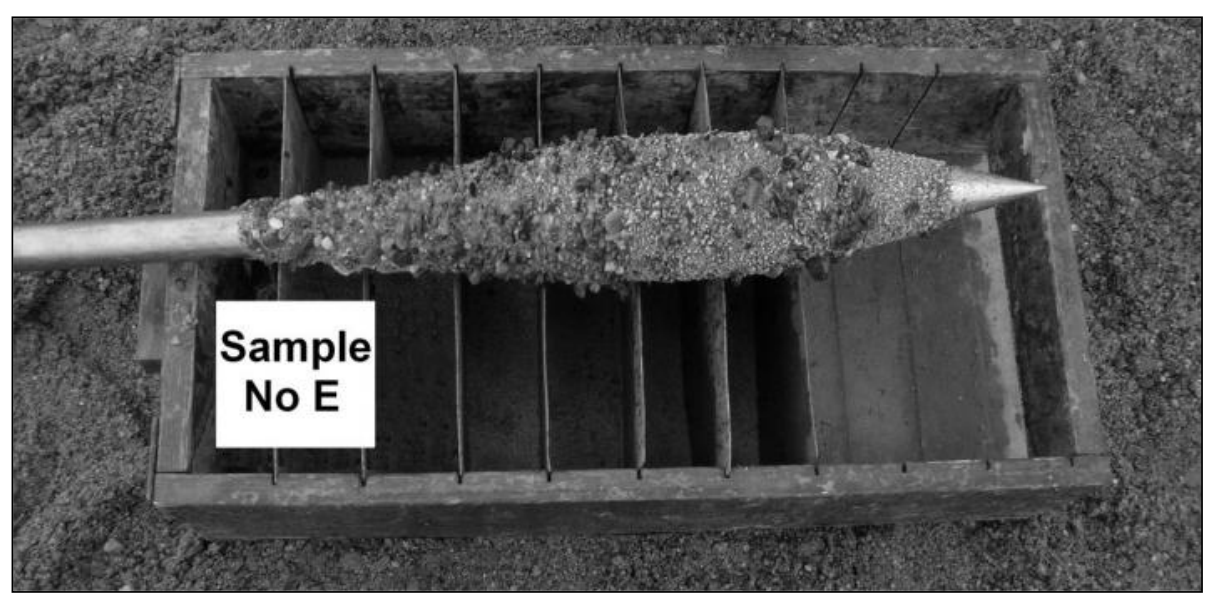


Photo 2. Frozen sample of the sand-gravel bed material, the Raba River, km 0+560, July 2005 (photo by $A$. Radecki-Pawlik).

\subsection{Modeling of morphodynamic conditions}

Within the present analysis a CCHE2D, the model developed in the University of Mississippi a two-dimensional steady and unsteady open channel flow and sediment transport model for non-equilibrium transport of non-uniform sediment mixtures - was applied as a river bed morphological tool. The model was used to simulate the morphodynamic changes along the outlet of the Raba River basing on field observations and measurements of the summer flood during 2005 year [Książek and Radecki-Pawlik 2008]. The depth integrated twodimensional equations of continuity and momentum are solved in the model [Jia and Wang 2001a, Wu and Wang 2000]. The sediment transport capacity can be determined with four modules [Wu 2001]. The model takes into consideration the bedload motion affected by transversal slope and by the secondary flows. The critical shear stress obtained from flat bed assumptions has to be corrected according to the slope angles in the stream-wise and transversal directions. Furthermore, secondary currents are generated due to the centrifugal force, bed load always tends to move towards to the inner bank of the channel, which systematically makes the channel more and more curved/meandrous. Despite model verification and validation there are some differences between observed and calculated data. For discharge $1644\left[\mathrm{~m}^{3} \cdot \mathrm{s}^{-1}\right]$ the average difference between predicted water surface level (WSL) and observed data was $0.16 \mathrm{~m}$ and the relative error is less than $8.0 \%$ [Xu et al. 2001]. Discrepancies between the computed results and measurements data scatters may be due to errors: in the measurements, due to depth-averaged model approximation, created in interpolation, bed elevation data used in computation are different from those during field data collection, errors caused by the adoption of a Manning's $n$. These factors would cause error in velocity distribution in the cross-sections as well as the velocity directions at each point. Nevertheless the overall agreement is still very good [Jia and Wang 2001b]. The first step to start simulations is creating a mesh [Zhang and Jia 2005]. The mesh was generated based on the surveyed topography. There are several methods to interpolate the interior nodes in the mesh, and later, to smooth the already created mesh. Once an appropriate mesh is generated, the elevation values are assigned to the nodes to create topography of the research area. The models such as the CCHE2D need to be tested in the field to understand bed forming process to interpret later the influence of hydrodynamics of river channel morphology and finally one, sooner or later, would like to use the model in different conditions even without possibility of comparing the model results with field results and still have good approximation.

The measurements within the Raba River were carried out in 78 cross-sections along a $730 \mathrm{~m}$ - long reach (Fig. 3 and 4) in the July campaign and 59 cross-section along a $920 \mathrm{~m}$ in the October one. The distance between cross-sections was from $5 \mathrm{~m}$ to $20 \mathrm{~m}$. The width of water surface during measurements varied from 30 to 38 meters. The density of measured points was about 1 survey spots per $32 \mathrm{~m}^{2}$. 


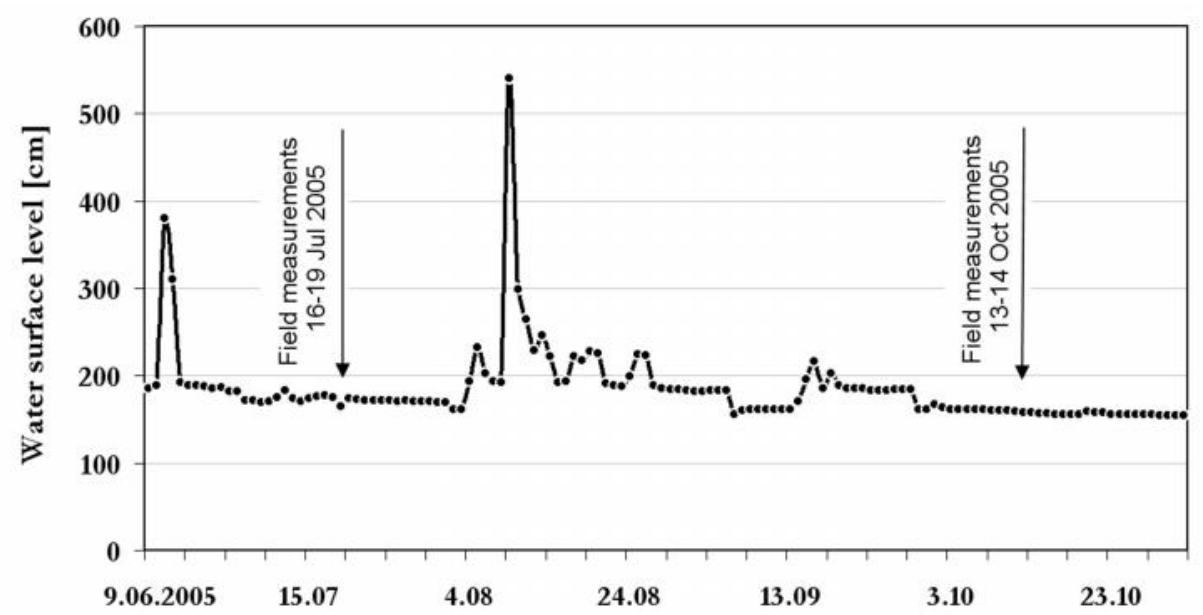

Date

Figure 3. Hydrograph of the Raba River at Proszówki gauge station - summer - 2005 [IMGW 2005]

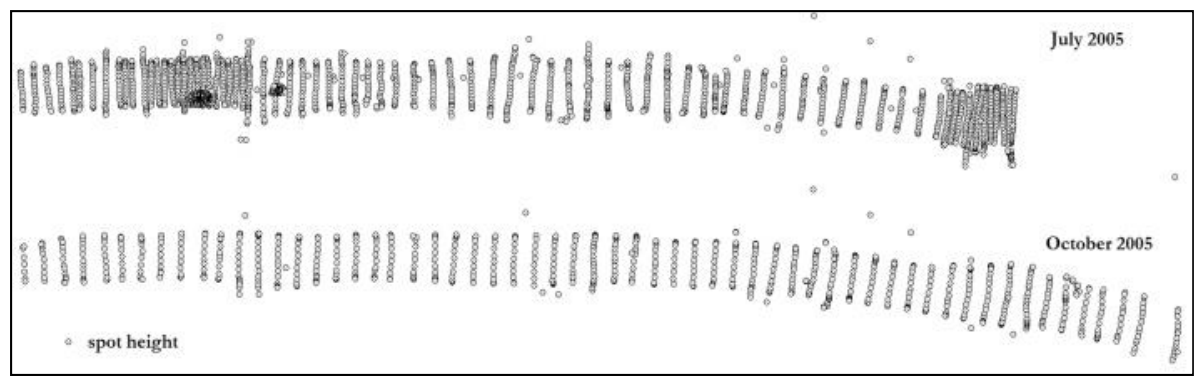

Figure 4. The measuring survey points of riverbed along the outlet the Raba River

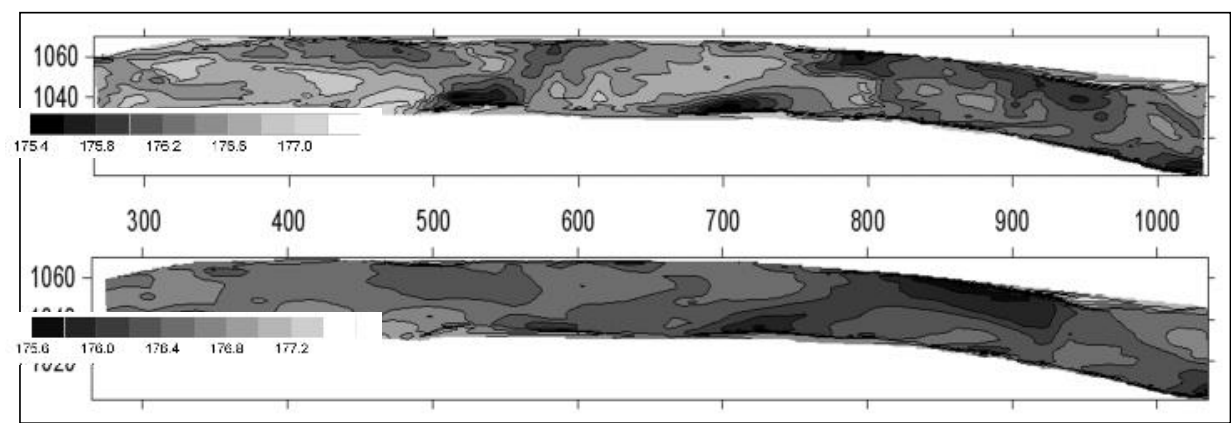

Figure 5. The riverbed of the Raba configuration map for before and after major flood

In Figure 4 the Raba River bed topography is presented along the research reach. The pale color shows the regions with the highest altitude. The bedforms formed in places where the water depth was lower than the average. One can notice such places in cross-section km 0+592 and km $0+030$ (Fig. 5). Despite that along the research reach river banks are engineered the immanent tendency to meandering of the thalweg is visible. The riverbed slopes of the Raba River varies from a negative value to $44 \%$ with the average value $33 \%$. Figure 6 presents typical cross- 
sections of the Skawa River. Changes in riverbed configurations are also indicated. The local changes in altitude of the river channel bottom are from $0.5 \mathrm{~m}$ (in-deepening) or $1 \mathrm{~m}$ (up-rising).

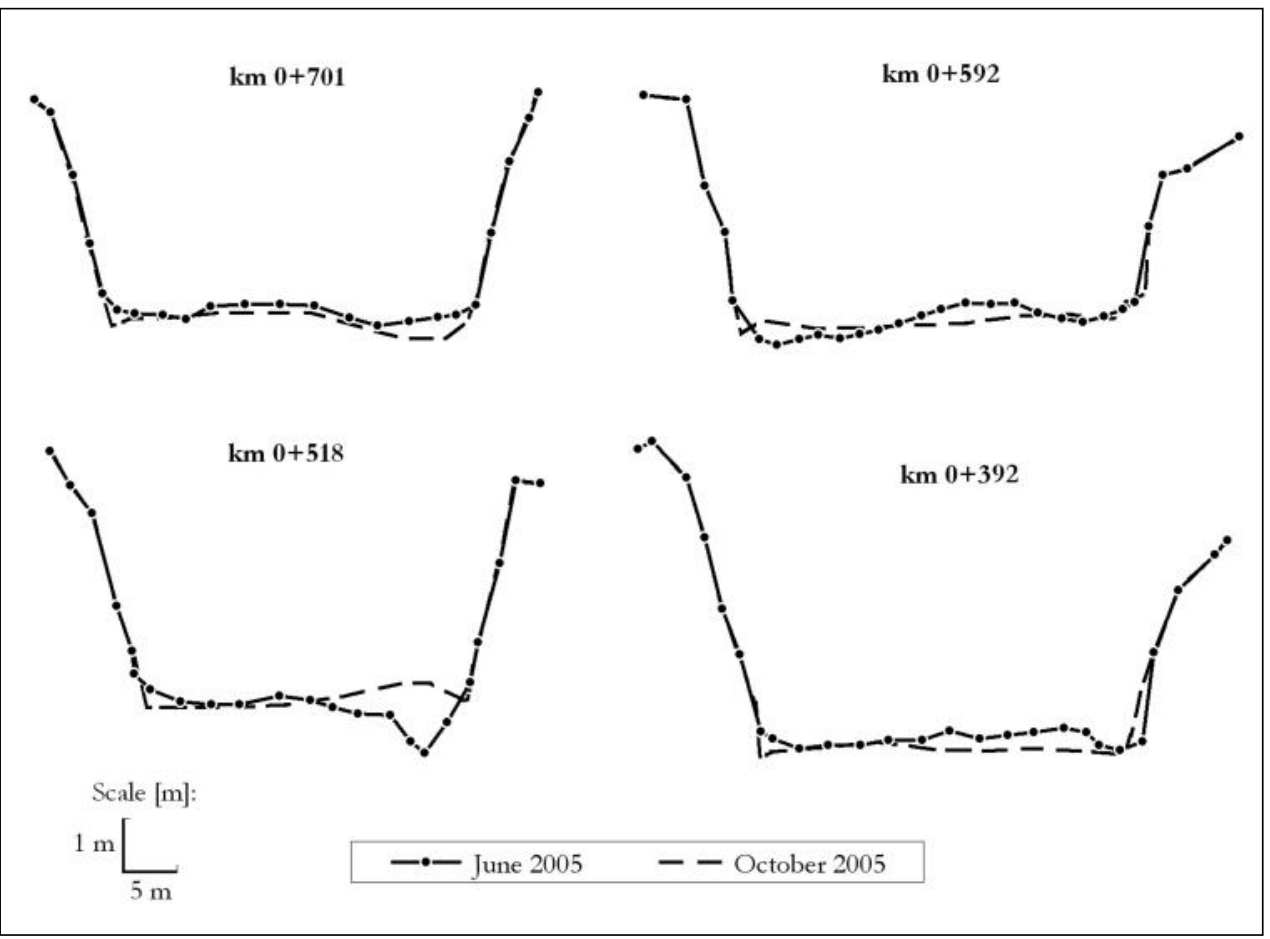

Figure 6. Examples of changes in the riverbed configuration after major flood

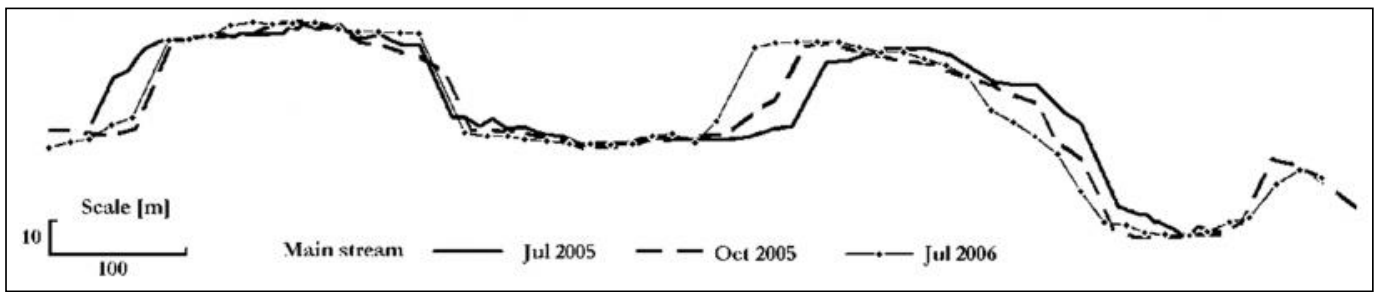

Figure 7. A path of the main stream at the research reach of the Raba River

Detailed analyses of the riverbed configuration show increasing tendency of the riverbed elevation with average value of $0.2 \mathrm{~m}$. After the bankfull stage - August 2005, the thalweg was shifted around $50 \mathrm{~m}$, but the meander-like system was preserved (with dimension up to $450 \mathrm{~m}$ ) (Fig. 7). After the next year flood, 2006 the meander-like system was still visible. Table 2 gives the values of the historical discharges as well as t-year flood probability. The major flood had the discharge value $Q=219\left[\mathrm{~m}^{3} \cdot \mathrm{s}^{-1}\right]$ and was less then discharge Q $50 \%=297\left[\mathrm{~m}^{3} \cdot \mathrm{s}^{-1}\right]$ which could be considered as bankfull here. The water surface level (WSL) at the research reach outlet was calculated using Chezy equation. 
Table 2. Water flow characteristic at the outlet of research reach of the Raba River

\begin{tabular}{lcc} 
Run description & $\begin{array}{c}\text { Discharge Q } \\
{\left[\mathrm{m}^{3} \cdot \mathrm{s}^{-1}\right]}\end{array}$ & $\begin{array}{c}\text { WSL at research reach } \\
{[\mathrm{m} \text { a.s.I.] }}\end{array}$ \\
\hline Q19Jul2005 & 7.0 & 176.70 \\
Q9Aug2005 & 218.5 & 180.38 \\
Q140ct2005 & 4.4 & 176.60 \\
Q30Mar2006 & 490 & 183.29 \\
Q25Jul2006 & 8.1 & 176.82 \\
\hline QSQ & 19.3 & $177.12^{*}$ \\
Q50\% & 297 & $181.36^{*}$ \\
Q20\% & 513 & $183.40^{*}$ \\
Q10\% & 706 & $184.52^{*}$ \\
Q1\% & 1303 & $186.12^{*}$ \\
\hline
\end{tabular}

*calculated

Judging on field measurements and hydraulic calculation the simulation of hydraulic conditions was next performed using numerical model which is described in the next chapter.

\section{Results and discussion}

For the reasons of clarity, all results of investigations and calculations are presented in tabular and graphic manner. In the table 3 the geometrical parameters are presented. To make the discussion clear and make it easy from research reach description point of view, the names: "Raba 1", "Raba 2" and „Raba 17" are used as it was done during the field work description respectively. Some details of those parameters were presented partly in conference paper in [Radecki-Pawlik et al. 2006, Słowik-Opoka 2006, Książek and Radecki-Pawlik 2008]. All the parameters presented within the table 3 are used for constructing Figures 8,9 and 10a, b. The discussion is provided below the graphs.

Every time the research reach in the field was visited, geometrical survey of bedforms were conducted, velocity profiles were obtained close to the bed as well as higher within the flow and sediments samples for granulometric analysis were obtained. Also, every time after major flooding (it has happened twice during the measuring campaign) a geodetic survey was made to get the river bed altitude details. Under low discharges (up to $3.9\left[\mathrm{~m}^{3} \cdot \mathrm{s}^{-1}\right]$ ) we noted that only sand ripples of heights $(\mathrm{H})$ up to tens millimeters were developing and moving along the full width of the research reach, whereas pre-existing sand-gravel bed forms were immobile on the armored bed.

When the discharge was larger (up to $11.4\left[\mathrm{~m}^{3} \cdot \mathrm{s}^{-1}\right]$ ) coarser bed load was moving, including over passing coarser grains over the crests of the sand-gravel features, which then began to migrate. Under the latter conditions sand ripples only developed close to the river banks where the flow velocity was lower than in the center of the channel, whereas sand-gravel barchanoid dunes were developing along the whole width of the channel although predominantly in the center. Fig. 8 presents measured heights $(H)$ of the investigated bed forms against their lengths $(L)$. 


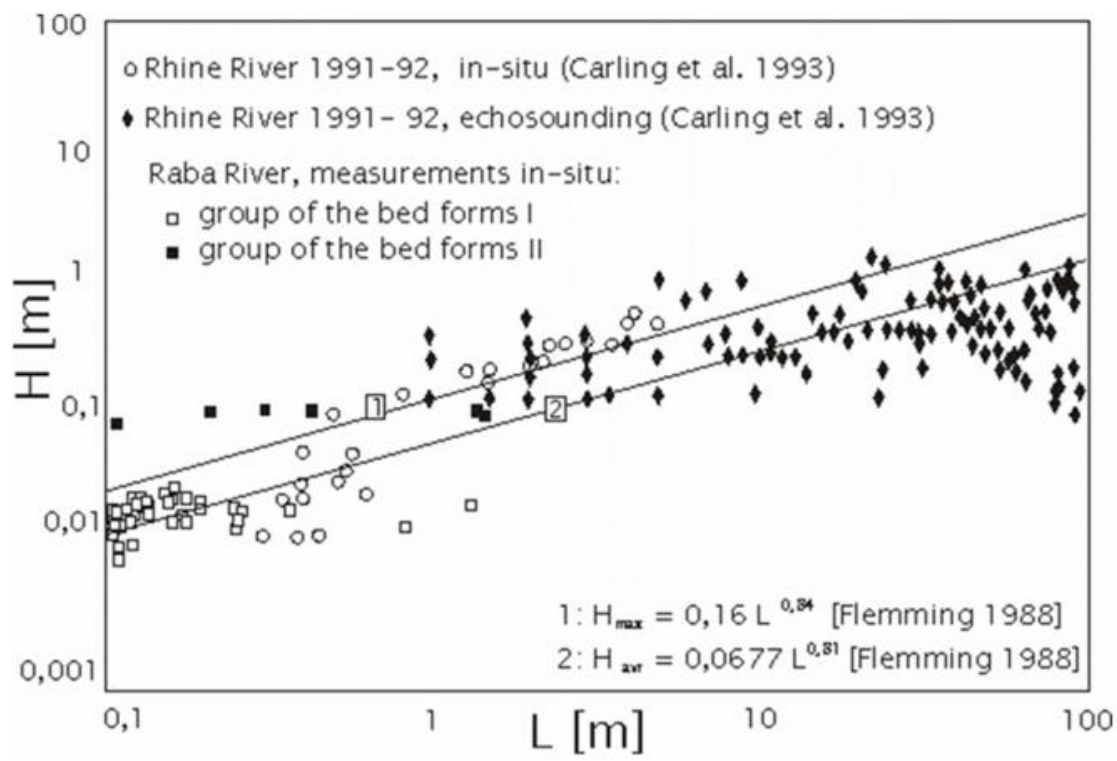

Figure 8. Height-length relation for the Raba River bed forms

Table 3. Measured dunes geometrical parameters results

\begin{tabular}{|c|c|c|c|c|c|c|c|c|}
\hline \multicolumn{2}{|c|}{ Research } & \multirow[b]{2}{*}{$\begin{array}{c}\text { Water } \\
\text { depth } h[m]\end{array}$} & \multicolumn{3}{|c|}{ Dune } & \multirow[b]{2}{*}{$\begin{array}{c}\mathrm{H} / \mathrm{L} \\
{[-]}\end{array}$} & \multirow[b]{2}{*}{$\begin{array}{c}W / L \\
{[-]}\end{array}$} & \multirow[b]{2}{*}{$\begin{array}{c}\mathrm{L} / \mathrm{H} \\
{[-]}\end{array}$} \\
\hline $\begin{array}{l}\text { Section } \\
\text { name }\end{array}$ & Point & & $\begin{array}{l}\text { height } \\
H[\mathrm{~m}]\end{array}$ & $\begin{array}{l}\text { length } \\
L[\mathrm{~m}]\end{array}$ & $\begin{array}{l}\text { width } \\
\text { W [m] }\end{array}$ & & & \\
\hline \multirow{4}{*}{ Raba 1} & P1 & 0.18 & \multirow{4}{*}{0.07} & \multirow{4}{*}{1.2} & \multirow{4}{*}{1} & \multirow{4}{*}{0.06} & \multirow{4}{*}{0.83} & \multirow{4}{*}{17.14} \\
\hline & P2 & 0.2 & & & & & & \\
\hline & P3 & 0.13 & & & & & & \\
\hline & P4 & 0.14 & & & & & & \\
\hline \multirow{4}{*}{ Raba 2} & P1 & 0.19 & \multirow{4}{*}{0.04} & \multirow{4}{*}{1.15} & \multirow{4}{*}{0.5} & \multirow{4}{*}{0.03} & \multirow{4}{*}{0.43} & \multirow{4}{*}{28.75} \\
\hline & P2 & 0.21 & & & & & & \\
\hline & P3 & 0.17 & & & & & & \\
\hline & P4 & 0.2 & & & & & & \\
\hline \multirow{16}{*}{ Raba 17} & 68 & 0.32 & 0.06 & 1.1 & 2.15 & 0.05 & 1.95 & 18.33 \\
\hline & 69 & 0.3 & 0.05 & 1.05 & 1.6 & 0.05 & 1.52 & 21 \\
\hline & 70 & 0.28 & 0.07 & 1.4 & 2.1 & 0.05 & 1.5 & 20 \\
\hline & 71 & 0.26 & 0.11 & 0.68 & 3.1 & 0.15 & 4.56 & 6.48 \\
\hline & 72 & 0.27 & 0.05 & 0.67 & 1.4 & 0.07 & 2.09 & 13.4 \\
\hline & 73 & 0.31 & 0.06 & 1.08 & 1.15 & 0.06 & 1.06 & 18 \\
\hline & 74 & 0.32 & 0.08 & 0.96 & 2 & 0.08 & 2.08 & 12 \\
\hline & 75 & 0.35 & 0.04 & 1.05 & 2.3 & 0.04 & 2.19 & 26.25 \\
\hline & 76 & 0.29 & 0.11 & 0.83 & 1.4 & 0.13 & 1.69 & 7.55 \\
\hline & 77 & 0.3 & 0.08 & 1.25 & 2.4 & 0.06 & 1.92 & 15.63 \\
\hline & 78 & 0.3 & 0.07 & 1.42 & 1.7 & 0.05 & 1.2 & 20.29 \\
\hline & 79 & 0.31 & 0.08 & 0.85 & 2.6 & 0.09 & 3.06 & 10.63 \\
\hline & 80 & 0.3 & 0.06 & 1 & 3.48 & 0.06 & 3.48 & 18.18 \\
\hline & 81 & 0.31 & 0.06 & 0.73 & 3.43 & 0.08 & 4.7 & 12.17 \\
\hline & 82 & 0.34 & 0.04 & 0.97 & 2.55 & 0.04 & 2.63 & 27.71 \\
\hline & 83 & 0.35 & 0.06 & 0.97 & 2.47 & 0.06 & 2.55 & 17.64 \\
\hline
\end{tabular}




\begin{tabular}{cccccccc}
84 & 0.4 & 0.07 & 1.38 & 2.7 & 0.05 & 1.96 & 19.71 \\
85 & 0.43 & 0.07 & 1.45 & 1.5 & 0.05 & 1.03 & 20.71 \\
86 & 0.45 & 0.09 & 1.33 & 2.25 & 0.06 & 1.69 & 15.65 \\
87 & 0.46 & 0.12 & 0.76 & 1.37 & 0.16 & 1.8 & 6.33 \\
88 & 0.42 & 0.07 & 1.32 & 2.15 & 0.05 & 1.63 & 20.31 \\
89 & 0.47 & 0.07 & 1.8 & 1.76 & 0.04 & 0.98 & 25.71 \\
90 & 0.45 & 0.06 & 0.97 & 2.6 & 0.06 & 2.68 & 17.64 \\
91 & 0.46 & 0.09 & 0.83 & 2.57 & 0.11 & 3.1 & 9.22 \\
92 & 0.44 & 0.04 & 0.7 & 1.24 & 0.06 & 1.77 & 17.5 \\
93 & 0.51 & 0.06 & 1.46 & 1.27 & 0.04 & 0.87 & 26.55 \\
94 & 0.4 & 0.07 & 0.94 & 1.26 & 0.07 & 1.34 & 14.46 \\
95 & 0.37 & 0.03 & 0.83 & 3.2 & 0.04 & 3.86 & 27.67 \\
96 & 0.4 & 0.08 & 1.15 & 3.3 & 0.07 & 2.87 & 14.38 \\
97 & 0.38 & 0.08 & 0.73 & 2.2 & 0.11 & 3.01 & 9.13 \\
98 & 0.35 & 0.04 & 0.64 & 1.3 & 0.06 & 2.03 & 16 \\
99 & 0.35 & 0.04 & 0.65 & 1.4 & 0.06 & 2.15 & 16.25 \\
100 & 0.43 & 0.05 & 0.93 & 2 & 0.05 & 2.15 & 18.6 \\
101 & 0.46 & 0.08 & 0.61 & 2.1 & 0.13 & 3.44 & 7.63 \\
102 & 0.51 & 0.05 & 0.94 & 1.15 & 0.05 & 1.22 & 20.89 \\
\hline
\end{tabular}

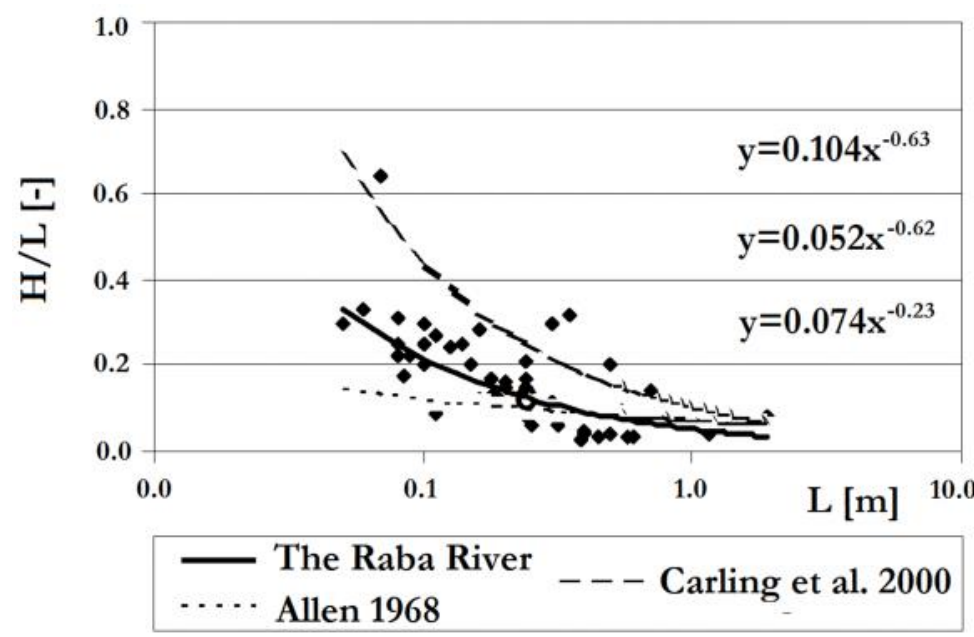

Figure 9. Steepness index (H/L) of the Raba River bed forms against their lengths $(L)$

The Raba data are compared with Flemming [1988] central tendency and limit lines as well as with bigger sand dunes found on the bed of the River Rhine [Carling et al. 2005, Carling et al. 2000]. The Raba data we divided in Figure 3 into two groups: Type 1 with the $1<\mathrm{d} 50<2.4 \mathrm{~mm}$ and $L<0.6 \mathrm{~m}$ which are here termed bed forms I and the second, Type 2, which are longer with 4 $<\mathrm{d} 50<11 \mathrm{~mm}$, which are termed bed forms II. The relation between Raba features describes the relation: $H=0.05 \mathrm{~L} 0.35$ ( $\mathrm{r} 2=0.47 ; \mathrm{F} 0.05(1 ; 55)=3.95 ; \alpha=0.05 ; \mathrm{n}=57$ ). The Raba type 1 bed forms are much shorter and smaller then the Rhine features and are also mostly below the upper limit given by Flemming [1988]. Type 2 bed forms are steep and lie above Flemming's curve. Raba bed forms are steeper (Fig. 9) then dunes described by Allen [1968] but flatter then the Rhine long sand dunes. Their H/L index = $0.0518 \mathrm{~L} 0.622$ ( $r 2=0.71 ; \mathrm{F} 0.05(1 ; 51)=7.24 ; \alpha=0.05 ; n=52$ ). Also plotted are the geometrical lengths and height of the Raba features against water depth 
(Fig. $10 \mathrm{a}, \mathrm{b}$ ), they lie close to the Yalin [1964] middle curve as far as their length (L) is concerned but some of them are higher $(\mathrm{H})$ than the maximum limitation. This may be because the higher bed forms has formed under a previous discharge when water depths were greater and have not yet fully readjusted their morphology.

- River Rhine 1992 [Carling et al. 1993]

\section{- Raba River}
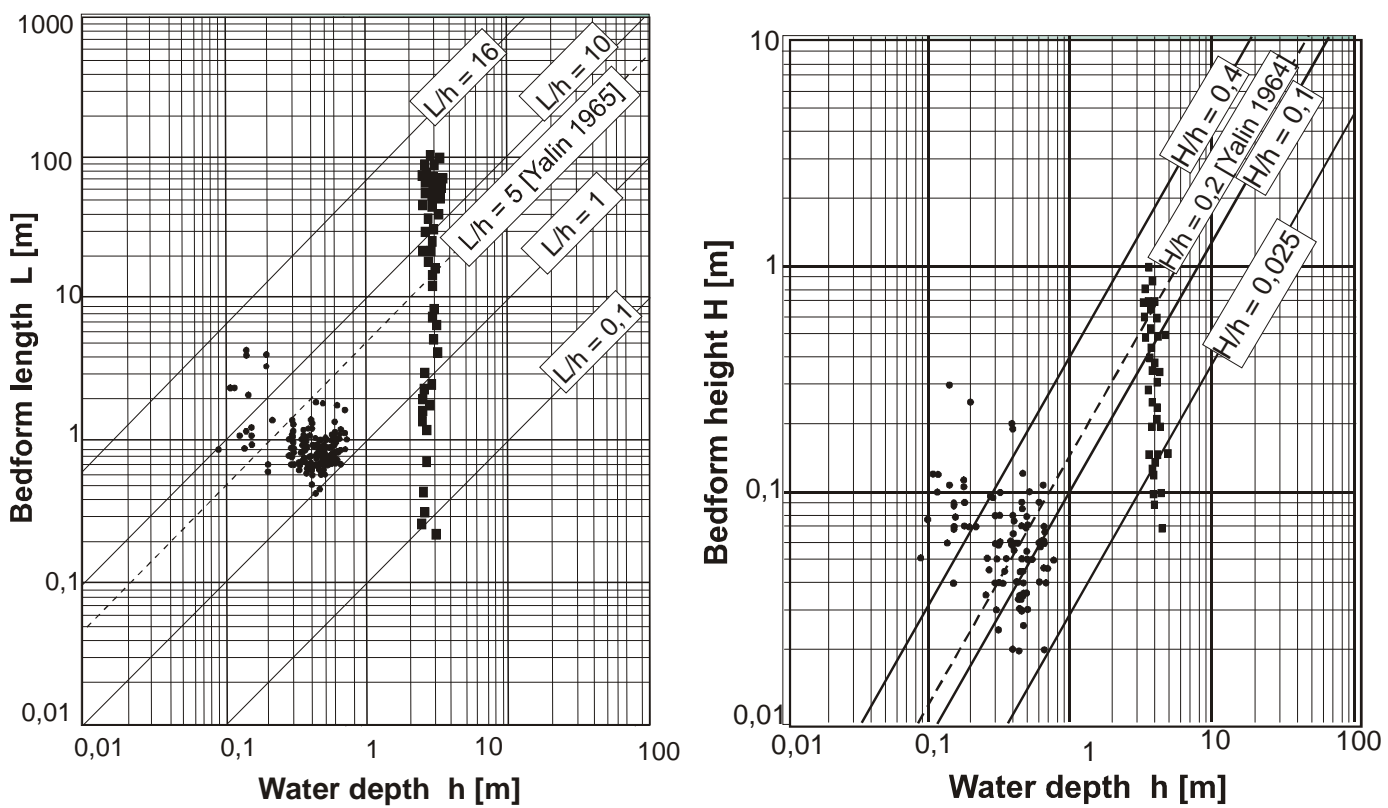

Figures 10 a, b. Lengths $(L)$ and heights $(H)$ of investigated bed forms against water depth $(h)$

Next, Tab. 4 presents examples of hydraulic parameters calculated for sand-gravel dunes we found during the investigations. Some examples of grain size curves of individual dunes are gathered within the Fig. 11. The shear stresses were not sufficient to disrupt the armoring layer of the sediment river bed. However, under the highest measured values coarse sediment movement occurred over the sand-gravel features and intensive sedimentation occurred at the toes of the bed forms. Also the sand ripples were transported, building and then decaying rapidly in different parts of the flat gravel armored river bed. The smaller features were moving with a celerity of $5 \mathrm{~cm} \cdot \mathrm{s}^{-1}$ and larger $-2 \mathrm{~cm} \cdot \mathrm{s}^{-1}$.

The results of detailed measured and calculated hydraulic parameters for the groups of identified sand-gravel dunes along the research reach: "Raba 3", "Raba 8" and "Raba 12" are gathered in Table 6. Here also the same names of groups were used as it was during the field campaign. The names R-5, R-6, W, W-1, W-2 and W-3 were dunes names along the sub-reaches listed above. As one can notice the R-5 dune was formed for the water velocity from $0.39 \mathrm{~m} \cdot \mathrm{s}-1$ to $0.47 \mathrm{~m}^{\cdot-1}$, for the crest $v=0.39 \mathrm{~m}^{\cdot} \mathrm{s}^{-1}$. The biggest shear velocity was for the stoss $=0.04 \mathrm{~m}^{-1} \mathrm{~s}^{-1}$ as it was for the $\tau$ $=1.334 \mathrm{~N} \cdot \mathrm{m}^{-2}$ value, whereas the crest $\tau$ is twice smaller $\left(\tau=0.565 \mathrm{~N} \cdot \mathrm{m}^{-2}\right)$. Consequently the biggest Shields parameter $\theta=0.0294$ was found over the stoss, whereas crest Shields stresses were $\theta=0.0125$. As it is suggested by Carling [1999] the values of those variables shows that the dune was within the flattening faze. 


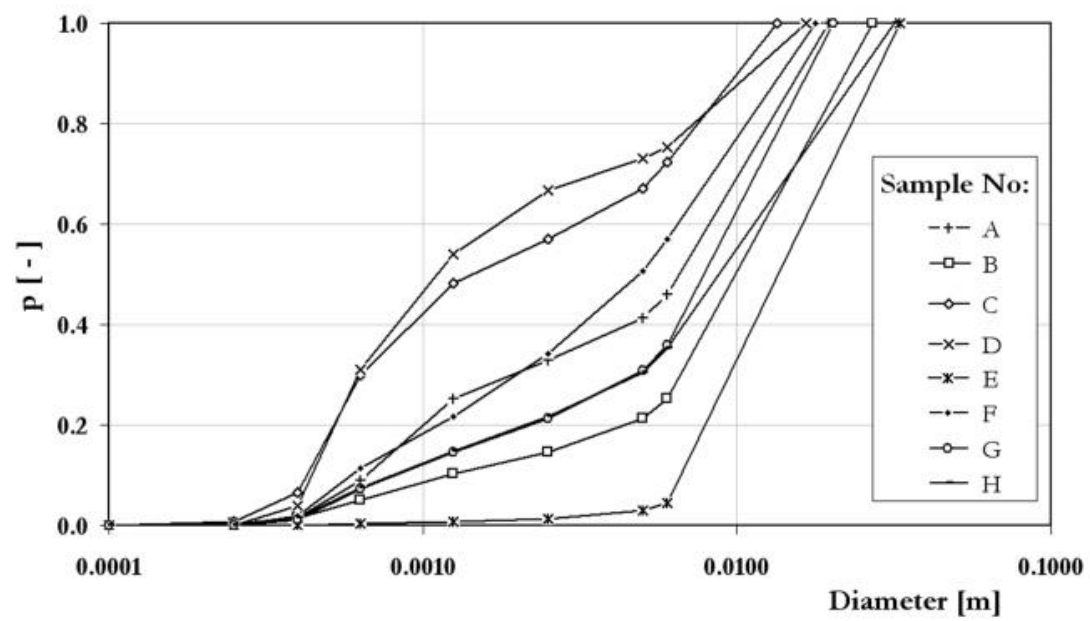

Figure 11. Grain size curve of investigated surface bed forms in different measuring points - examples

Generally, it was observed that when $\tau<0.29 \mathrm{~N} \cdot \mathrm{m}^{-2}$ no dune formation process was presented. Also form data from Table 6 , it is visible that for all research reaches the friction coefficients $f 1=$ $0.0652, \mathrm{f} 2=0.0011$ and $\mathrm{f} 3=0.0012$ are the biggest for stoss and the smallest for trough. Crest friction is respectively $\mathrm{f} 1=0.0297, \mathrm{f} 2=0.0004$, and $\mathrm{f} 3=0.0005$.

Table 4. Hydrodynamical parameters within the region of researched dunes

\begin{tabular}{|c|c|c|c|c|c|c|c|c|c|c|c|}
\hline \multirow{2}{*}{ Reach } & \multirow{2}{*}{\multicolumn{2}{|c|}{$\begin{array}{l}\text { Dune } \\
\text { Dune point }\end{array}$}} & \multicolumn{2}{|c|}{$\begin{array}{c}\text { Velocity }\left[\mathrm{m} \cdot \mathrm{s}^{-}\right. \\
\left.{ }^{1}\right]\end{array}$} & \multirow{2}{*}{$\begin{array}{c}\tau \\
{\left[\mathrm{N} \cdot \mathrm{m}^{-2}\right]}\end{array}$} & \multirow[t]{2}{*}{$\theta$} & \multicolumn{3}{|c|}{ Friction coefficient } & \multirow{2}{*}{$\mathrm{Fr}$} & \multirow{2}{*}{$\begin{array}{l}\mathrm{d}_{50} \\
{[\mathrm{~m}]}\end{array}$} \\
\hline & & & $\mathrm{V}$ & $\mathrm{v}^{*}$ & & & $f_{1}[-]$ & $\underline{f_{2}[-]}$ & $f_{3}[-]$ & & \\
\hline \multirow{10}{*}{ Raba 3} & \multirow{5}{*}{ R-5 } & P1 & 0.47 & 0.02 & 0.566 & 0.0125 & 0.0205 & 0.0004 & 0.0005 & 0.43 & \multirow[t]{5}{*}{0.0028} \\
\hline & & P2 & 0.44 & 0.02 & 0.566 & 0.0125 & 0.0250 & 0.0004 & 0.0005 & 0.47 & \\
\hline & & P3 & 0.39 & 0.02 & 0.565 & 0.0125 & 0.0297 & 0.0004 & 0.0005 & 0.36 & \\
\hline & & P4 & 0.39 & 0.04 & 1.334 & 0.0294 & 0.0652 & 0.0011 & 0.0012 & 0.39 & \\
\hline & & P5 & 0.40 & 0.03 & 1.092 & 0.0241 & 0.0545 & 0.0009 & 0.0010 & 0.39 & \\
\hline & \multirow{5}{*}{ R-6 } & P1 & 0.41 & 0.02 & 0.327 & 0.0096 & 0.0156 & 0.0003 & 0.0003 & 0.38 & \multirow[t]{5}{*}{0.0021} \\
\hline & & P2 & 0.40 & 0.01 & 0.151 & 0.0044 & 0.0076 & 0.0001 & 0.0001 & 0.34 & \\
\hline & & P3 & 0.42 & 0.02 & 0.302 & 0.0089 & 0.0140 & 0.0002 & 0.0003 & 0.34 & \\
\hline & & P4 & 0.36 & 0.02 & 0.573 & 0.0168 & 0.0354 & 0.0005 & 0.0005 & 0.32 & \\
\hline & & P5 & 0.36 & 0.03 & 0.799 & 0.0235 & 0.0493 & 0.0006 & 0.0007 & 0.33 & \\
\hline \multirow{5}{*}{ Raba 8} & \multirow{5}{*}{ W } & P5 & 0.19 & 0.01 & 0.115 & 0.0018 & 0.0254 & 0.0002 & 0.0001 & 0.16 & \multirow[t]{5}{*}{0.0080} \\
\hline & & P4 & 0.32 & 0.02 & 0.448 & 0.0062 & 0.0326 & 0.0006 & 0.0002 & 0.22 & \\
\hline & & P3 & 0.47 & 0.03 & 0.717 & 0.0076 & 0.0258 & 0.0009 & 0.0004 & 0.75 & \\
\hline & & P2 & 0.34 & 0.01 & 0.132 & 0.0012 & 0.0086 & 0.0002 & 0.0001 & 0.30 & \\
\hline & & P1 & 0.38 & 0.02 & 0.421 & 0.0037 & 0.0239 & 0.0005 & 0.0002 & 0.27 & \\
\hline \multirow{12}{*}{$\begin{array}{l}\text { Raba } \\
12\end{array}$} & \multirow{4}{*}{ W1 } & P4 & 0.61 & 0.02 & 0.427 & 0.0038 & 0.0092 & 0.0013 & 0.0013 & 0.37 & \multirow[t]{4}{*}{0.0070} \\
\hline & & P3 & 0.52 & 0.02 & 0.413 & 0.0036 & 0.0122 & 0.0013 & 0.0013 & 0.33 & \\
\hline & & P2 & 0.56 & 0.02 & 0.377 & 0.0033 & 0.0096 & 0.0012 & 0.0012 & 0.41 & \\
\hline & & P1 & 0.40 & 0.02 & 0.521 & 0.0046 & 0.0261 & 0.0016 & 0.0016 & 0.26 & \\
\hline & \multirow{4}{*}{ W2 } & P1 & 0.34 & 0.04 & 1.592 & 0.0089 & 0.1102 & 0.0049 & 0.0049 & 0.25 & \multirow[t]{4}{*}{0.0110} \\
\hline & & P2 & 0.81 & 0.02 & 0.607 & 0.0034 & 0.0074 & 0.0019 & 0.0019 & 0.67 & \\
\hline & & P3 & 0.66 & 0.01 & 0.194 & 0.0011 & 0.0036 & 0.0006 & 0.0006 & 0.44 & \\
\hline & & P4 & 0.50 & 0.02 & 0.432 & 0.0024 & 0.0138 & 0.0013 & 0.0013 & 0.24 & \\
\hline & \multirow{4}{*}{ W3 } & P1 & 0.42 & 0.04 & 1.335 & 0.0118 & 0.0605 & 0.0041 & 0.0041 & 0.27 & \multirow[t]{4}{*}{0.0070} \\
\hline & & P2 & 0.79 & 0.02 & 0.552 & 0.0049 & 0.0071 & 0.0017 & 0.0017 & 0.63 & \\
\hline & & P3 & 0.72 & 0.01 & 0.207 & 0.0018 & 0.0032 & 0.0006 & 0.0006 & 0.49 & \\
\hline & & P4 & 0.52 & 0.03 & 0.870 & 0.0077 & 0.0258 & 0.0027 & 0.0027 & 0.29 & \\
\hline
\end{tabular}


Dune R-5 was fine gravel dune with $\mathrm{d} 50=0.0028 \mathrm{~m}$ and was formed for crest $\mathrm{Fr}=0.36$ and stoss $\mathrm{Fr}=0.47$. According to Carling [1999] it was 2D fine-gravel dune. It had barchanoid like shape. Within the reach Raba 3 dune R- 6 was very fine gravel dune of parabolic shape with $d_{50}=0.0021$ $\mathrm{m}$. Here the biggest $\mathrm{v}=0.42 \mathrm{~m}^{*} \mathrm{~s}-1$ was observed when the dune was formed along the velocity profile as well as the biggest value of stoss $v_{*}=0.03 \mathrm{~m} \cdot \mathrm{s}^{-1}$ and stoss $\tau=0.799 \mathrm{~N} \cdot \mathrm{m}^{-2}$ was calculated. Water depth over the crest R-6 dune was maximum $0.15 \mathrm{~m}$. Within Raba 8 reach, the dune $W$ is a gravel dune with $d_{50}=0.008 \mathrm{~m}$, with barchanoid shape. The height for the dune was $0.16 \mathrm{~m}$, its length $1.80 \mathrm{~m}$ and maximum width $2.50 \mathrm{~m}$. During field measurement the water discharge $Q$ was $3.90\left[\mathrm{~m}^{3} \cdot \mathrm{s}^{-1}\right]$. Gravel dunes from the reach Raba 12 are all gravel dunes W1, W2 and W3 with d50 respectively: $0.007,0.011$ and $0.007 \mathrm{~m}$. W1 is $0.09 \mathrm{~m}$ high, with the length 1.6 $\mathrm{m}$ and width $6.5 \mathrm{~m}$. W2 is 2 times larger then W1 whereas $\mathrm{W} 3$ is similar in geometric dimensions to W1. All those forms are parabolic.

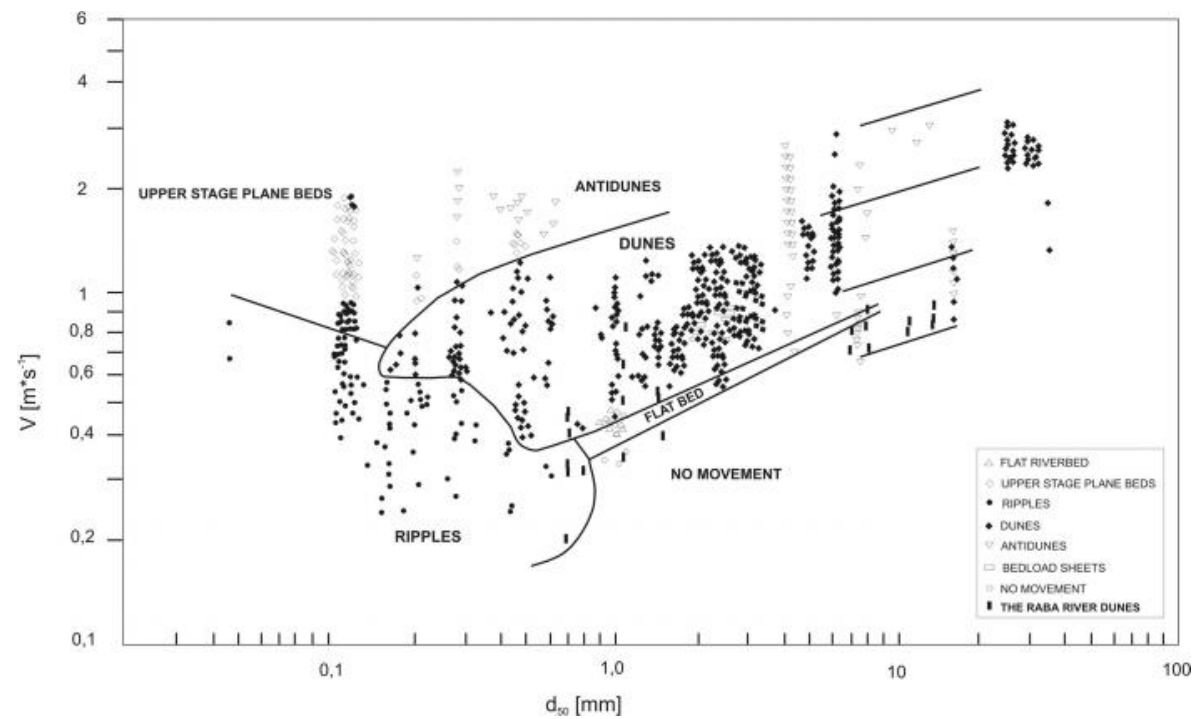

Figure 12. Velocity of the flowing water versus dimension of grains - notice the Raba sand-gravel bed form results (from Carling [1999], extended).

In 1999 Carling presented the extended graph of the mean velocity - median sediment size. First time the gravel dunes data were put into this graph by Carling and the graph was extended up to $d=33 \mathrm{~mm}$. Here along the paper the new data from the Raba outlet can also fulfill the information of the possibility of existence the sand-gravel bed forms, which are dunes where the detailed field measurements were performed during described field campaign. The new data, also like in Carling's classic paper, were not temperature adjusted to $10^{\circ} \mathrm{C}$, but the temperature that was measured during measurements was always between $10-12^{\circ} \mathrm{C}$, which not affected the obtained results.

\subsection{Modeling with CCHE2D - Hydraulic conditions}

The CCHE2D [Jia and Wang 2001a] model simulations were carried out for the water discharges varying from $4.4\left[\mathrm{~m}^{3} \cdot \mathrm{s}^{-1}\right]$ to $1303\left[\mathrm{~m}^{3} \cdot \mathrm{s}^{-1}\right]$ (Table 2). It was done for steady conditions and the for summer flood with unsteady conditions with and without backwater effect from the Vistula River. This two-dimensional unsteady flow and sediment transport model was applied to simulate the morphodynamic changes along the outlet of the Raba River, basing on field 
observations of the 2005 summer flood to test and confirm the range of morphodynamic changes, which take place along the research reach where the dunes are being developed.

The mesh of the model consists of $20 \times 450$ cells. The dimensions of individual cells are about $1.7 \times 2.0 \mathrm{~m}$. The Manning's coefficient calibrated varies from 0.010 to 0.029 in the main channel. During calibration procedure the measured and calculated WSL ware evaluated using dimensionless model evaluation statistics: Nash-Sutcliffe efficiency NSE, and error indexes: percentage bias PBIAS and RMSE-observations standard deviation ratio RSR coefficients. Those rating parameters are adopted from hydrological data [Nash and Sutcliffe 1970]. Data series are given for selected cross-section, for selected gauging station and daily or monthly time steps. Water depth, instead WSL, is chosen as its more sensitive for differences between measured and calculated values. For the discharge $Q=7.0 \mathrm{m3s}-1 \mathrm{NSE}=0,98, \mathrm{PBIAS}=2,09 \%$ and $\mathrm{RSR}=0,13$, data number $n=25$. The values of NSE $>0.5$, PBIASflow $<10 \%$ and $R S R<0.5$ ratings the model as very good [Moriasi et al. 2007].

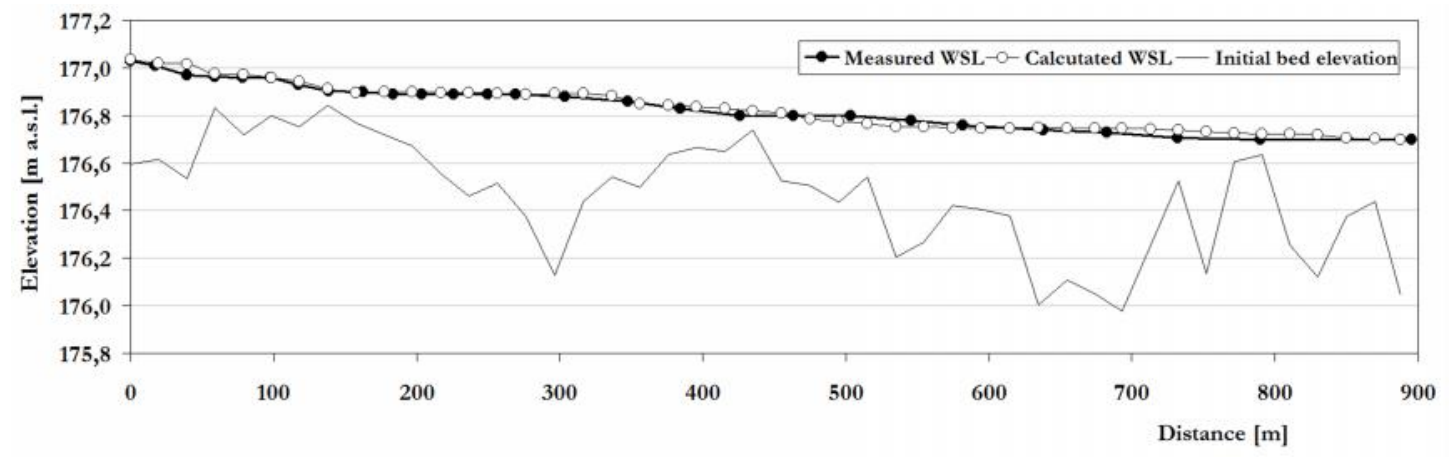

Figure 13. Measured and calculated water surface level (WSL) for discharge $Q=4.4 \mathrm{m3} \cdot \mathrm{s}-1$, Jul 2005

There are measured and calculated water surface levels (WSL) for discharge $Q=7.0\left[\mathrm{~m}^{3} \cdot \mathrm{s}^{-1}\right]$ in Fig. 13. The differences between the calculated and measured water surface elevation do not exceed $0.05 \mathrm{~m}$ and model evaluation statistics rating is very good.

The calculated WSL for discharge $Q=4.4\left[\mathrm{~m}^{3} \cdot \mathrm{s}^{-1}\right]$ average slope is $0.28 \%$ (Tab. 3), which means it is nearly the measured one, which is equal to $0.31 \%$. For discharge $Q=7.0\left[\mathrm{~m}^{3} \cdot \mathrm{s}^{-1}\right] \mathrm{WSL}$ average slopes are $0.40 \%$ and $0.36 \%$ respectively.

Fig. 14 presents velocity vectors for discharge $Q=16.0\left[\mathrm{~m}^{3} \cdot \mathrm{s}^{-1}\right] \quad(\mathrm{t}=0)$ and $\mathrm{Q}=218.5\left[\mathrm{~m}^{3} \cdot \mathrm{s}^{-1}\right]$ (peak flood). For low discharges within the research reach, main stream flows alternately along left and right banks create meander-like system whereas for high discharges the flow field is uniform.

The WSL slope during summer flood differs for the same stages depending on the stage of the flood event and backwater effect (Fig. 15a). Without backwater effect for the same water depths for incoming flood the average WSL slope is higher than when flood decreasing. That phenomena is typical for open channel flow and was observed previously by Meirovich et al. [1998] who investigated influence of water slope on bedload transport intensity. With consideration of the backwater effect from the Vistula River the WSL slope is smaller when the flood is increasing than when it is decreasing. 


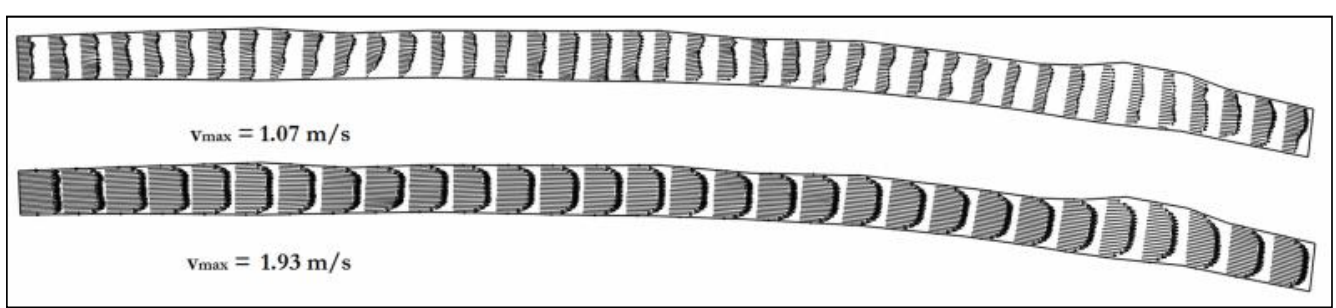

Figure 14. Velocity vectors for discharges $Q=16,0 \mathrm{~m}^{3} \cdot \mathrm{s}^{-1}$ and $Q=218,5 \mathrm{~m}^{3} \cdot \mathrm{s}^{-1}$
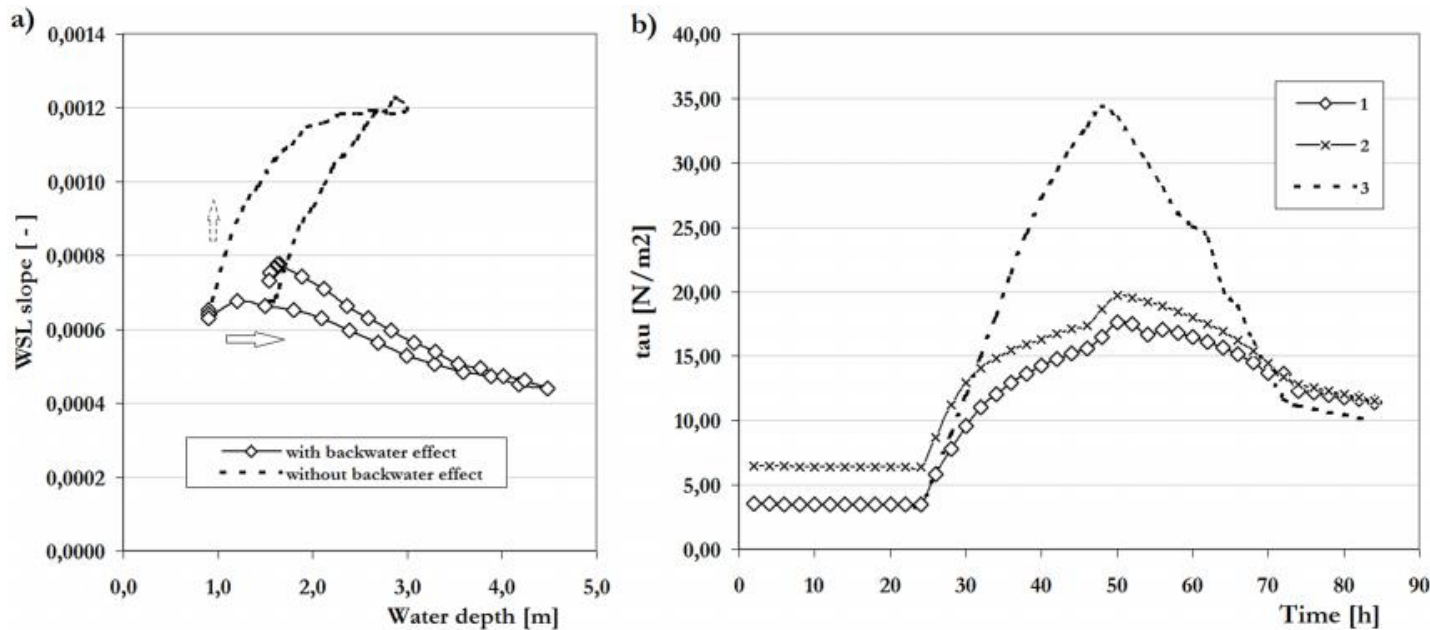

Figure 15. Calculated flow conditions for summer flood; a) changes of WSL slope with and without backwater effect, b) shear stresses over the crest (1), in the middle of thalweg (2) with backwater effect and over the crest without backwater effect (3)

The maximum water flow velocity and the shear stresses for the summer flood caused the hydrodynamic conditions when water velocity as well as shear stresses values reached respectively up to $v=1.93 \mathrm{~m} \cdot \mathrm{s}^{-1}$, and $\tau=19.74 \mathrm{~N} \cdot \mathrm{m}^{-2}$, which shows that critical conditions of bed load movement were exceed for the Raba estuary. The incipient motion criterion for bedload transport is often based on the critical shear stress. Fig. 15b presents calculated shear stresses for major flood where maximum value in the middle of the thalweg raise up to $\tau=19.74 . \mathrm{N} \cdot \mathrm{m}^{-2}(I=15$, $\mathrm{J}=241)$ as well as over crest - up to $\tau=17.65 \mathrm{~N} \cdot \mathrm{m}^{-2}(\mathrm{I}=6, \mathrm{~J}=225)$ with back water effect and without $\tau=34.36 \mathrm{~N} \cdot \mathrm{m}^{-2}$. Tab. 5 presents calculated shear stresses $\tau$, velocity of water flow $\mathrm{v}$ and average slope of WSL for different flow conditions. For instance for discharge $Q=4.4 \mathrm{~m} 3 \mathrm{~s}-1$ maximum shear stress is equal to $4.1 \mathrm{~N} \cdot \mathrm{m}^{-2}$. At the major flood Q9Aug, shear stress reached $19.74 \mathrm{~N} \cdot \mathrm{m}-2$, flow velocity increased to $1.93 \mathrm{~m} \cdot \mathrm{s}^{-1}$. Calculations of critical shear stresses using equation $\tau \mathrm{cr}=\theta \cdot \mathrm{dm} \cdot \Delta \gamma \mathrm{s}$ with dimensionless Shields parameter equal to $\theta=0.033$ (which value was worked out in Department of Hydraulic Engineering and Geotechnics AUK [Michalik 1990] for the Raba River conditions) show that the critical shear stress along the research reach vary from $\tau \mathrm{cr}=1.1 \mathrm{~N} \cdot \mathrm{m}^{-2}$ to $\tau_{\mathrm{cr}}=6.9 \mathrm{~N} \cdot \mathrm{m}^{-2}$. 
Table 5. Calculated hydraulic parameters along the research reach of the Raba River

\begin{tabular}{ccccc}
\hline Run & Flow conditions & $\begin{array}{c}\text { WSL slope } \\
\mathrm{I}[\% \text { oo }]\end{array}$ & $\begin{array}{c}\text { Max velocity } \\
\mathrm{v}_{\max }\left[\mathrm{m} \cdot \mathrm{s}^{-1}\right]\end{array}$ & $\begin{array}{c}\text { Range of shear } \\
\text { stress } \tau\left[\mathrm{N} \cdot \mathrm{m}^{-2}\right]\end{array}$ \\
\hline $\mathrm{Q}_{140 \mathrm{Oct}}$ & Steady & 0.28 & 0.76 & $0.4-4.1$ \\
\hline $\mathrm{Q}_{19 \mathrm{Jul}}$ & Steady & 0.40 & 0.90 & $0.8-6.7$ \\
\hline $\mathrm{Q}_{\mathrm{sQ}}$ & Steady & 0.39 & 1.12 & $1.5-7.3$ \\
\hline & $\begin{array}{c}\text { Unsteady without } \\
\text { and with }\end{array}$ & $0.64-1.22$ & $1.26-2.42$ & $3.47-34.36$ \\
$\mathrm{Q}_{9 \text { Aug }}$ & $\begin{array}{c}\text { backwater effect } \\
\text { back }\end{array}$ & $0.44-0.78$ & $1.07-1.93$ & $2.79-19.74$ \\
\hline $\mathrm{Q}_{50 \%}$ & Steady & 0.21 & 2.12 & $6.0-12.6$ \\
\hline $\mathrm{Q}_{20 \%}$ & Steady & 0.23 & 2.59 & $9.3-16.5$ \\
\hline $\mathrm{Q}_{10 \%}$ & Steady & 0.31 & 3.11 & $11.8-22.5$ \\
\hline $\mathrm{Q}_{1 \%}$ & Steady & 0.65 & 4.78 & $23.6-50.4$ \\
\hline
\end{tabular}

Those values are exceeded in some reaches for all discharges. On the other hand, bedload transport occurs locally almost all over the year because the observed flow regime during field measurements was close to the minimum annual flow (see Tab. 1). Basing on numerical simulations it was found that $\tau \approx \tau_{\mathrm{cr}}$ for low discharges so this is the reason why bed forms exist despite riverbed material consisting of coarse material. For other flow situations the incipient values for the initiation of the bedload transport are exceeded and one can expect mass transport of the bed material.

\section{Modeling with CCHE2D - Bedload transport}

Bedload transport simulations with the CCHE2D model were carried out using Wu et al. module [Wu et al. 2000, Wu 2001] for unsteady conditions. During steady simulations the SEDTRA module was used in which bimodality parameter B defined by Wilcock was difficult to implement in order to take into account the hiding and exposure effect of nonuniform sediment mixture [Wu 2001]. The formula of Wu et al. for fractional bedload transport capacity which is a function of bed shear stress and critical shear stresses $\phi b k=f\left(\tau_{b} / \tau_{c r}\right)$ was calibrated using both set of laboratory and natural river data.

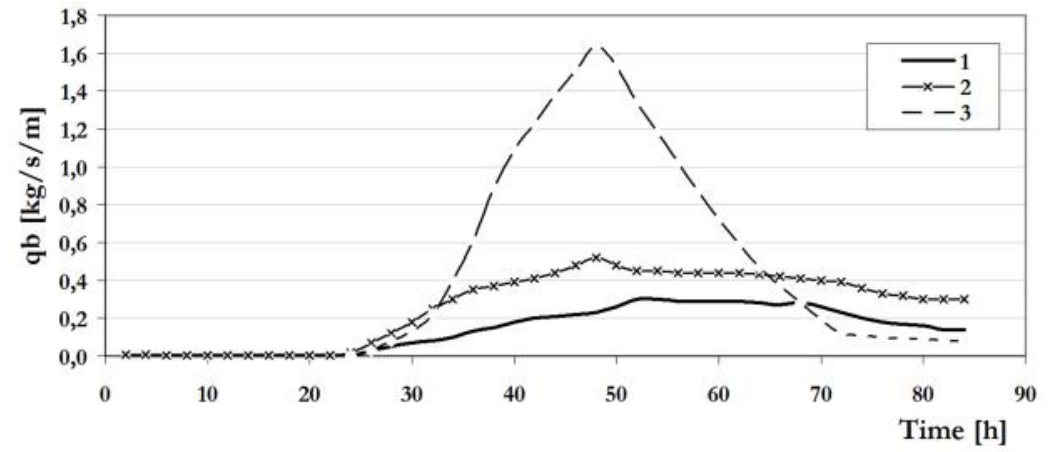

Figure 16. Bed load transport intensity over the crest (1), in middle of the thalweg (2) with backwater effect and over the crest without backwater effect (3), the summer flood 2005, the Raba River 
Next, for major flood - discharge Q9Aug $=218.5\left[\mathrm{~m}^{3} \cdot \mathrm{s}^{-1}\right]$ with and without backwater effect simulations were performed. Two sublayers has been defined as to take into account vertical sorting; with mean diameter $\mathrm{dm}=0.0076 \mathrm{~m}$ for the cover and $\mathrm{dm}=0.0045 \mathrm{~m}$ for sublayer. As a bedload boundary condition the results from a previous unsteady calculations were chosen with bedload transport intensity in the range $\mathrm{qb}=0.45 \mathrm{~kg} \cdot \mathrm{s}^{-1} \cdot \mathrm{m}^{-1}$.

The discharge is sufficient enough to entrain bed material to a motion. For steady conditions almost along the entire research reach, bedload transport has the intensity $\mathrm{qb}=0.32 \mathrm{~kg} \cdot \mathrm{s}^{-1} \cdot \mathrm{m}^{-1}$ and reaches in some places $\mathrm{qb}=0.61 \mathrm{~kg} \cdot \mathrm{s}^{-1} \cdot \mathrm{m}^{-1}$ [Książek and Radecki-Pawlik 2008] while for unsteady conditions bedload transport has the intensity $q b=0.30 \mathrm{~kg} \cdot \mathrm{s}^{-1} \cdot \mathrm{m}^{-1}\left(\mathrm{max} \mathrm{qb}=0.51 \mathrm{~kg} \cdot \mathrm{s}^{-1} \cdot \mathrm{m}^{-}\right.$ $\left.{ }^{1}\right)$. Fig. 16 presents intensity of bed load transport over the crest $(\mathrm{l}=6, \mathrm{~J}=225)$ and in the middle of the thalweg $(I=15, J=241)$ with backwater effect. Under natural conditions at the Raba River mouth one can observed bedload transport intensity during whole flood event. Usually, without back water effect in typical mountainous streams bedload transport is shorter but more intensive. Spatial distribution of bedload transport rate for discharge $Q=218.5 \mathrm{~m}^{3} \cdot \mathrm{s}^{-1}, \mathrm{t}=48 \mathrm{~h}$ is presented on Fig. 17.

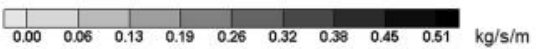

Figure 17. Calculated bedload transport rate for discharge $Q=218.5 \mathrm{~m}^{3} \cdot \mathrm{s}^{-1}$

From the given analysis one could expect deposition at the and of the research reach. Fig. 18 presents changes of riverbed configuration both measured and calculated. The differences in bed configuration vary from $-0.8 \mathrm{~m}$ (erosion) to $1.2 \mathrm{~m}$ (deposition). The results are in accordance with simulation where ranges of bed changes are the same; $-0,75 \div 0.6 \mathrm{~m}$. That changes are the results of the bed forms movement. As a result of the simulation riverbed bottom on average do not change.
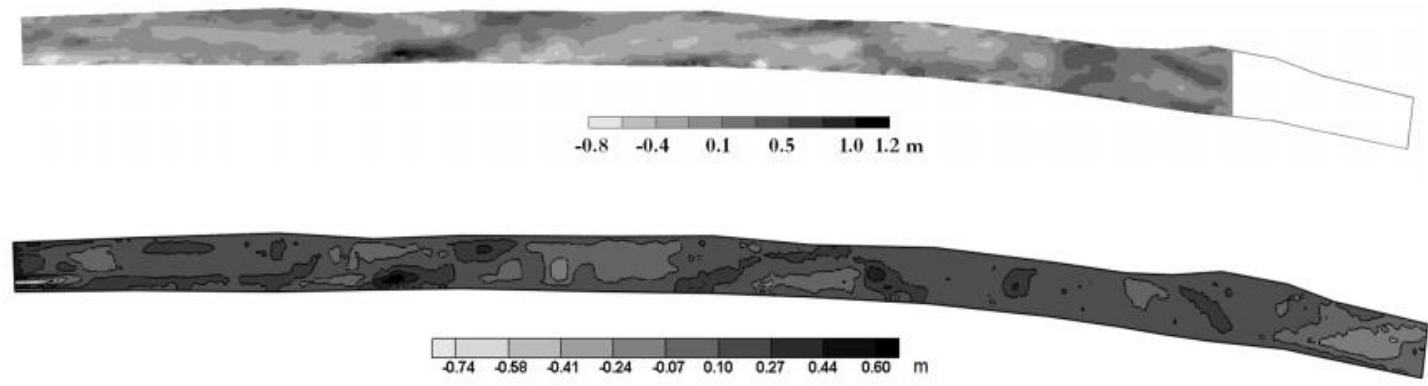

Figure 18. Measured and calculated changes of riverbed topography 


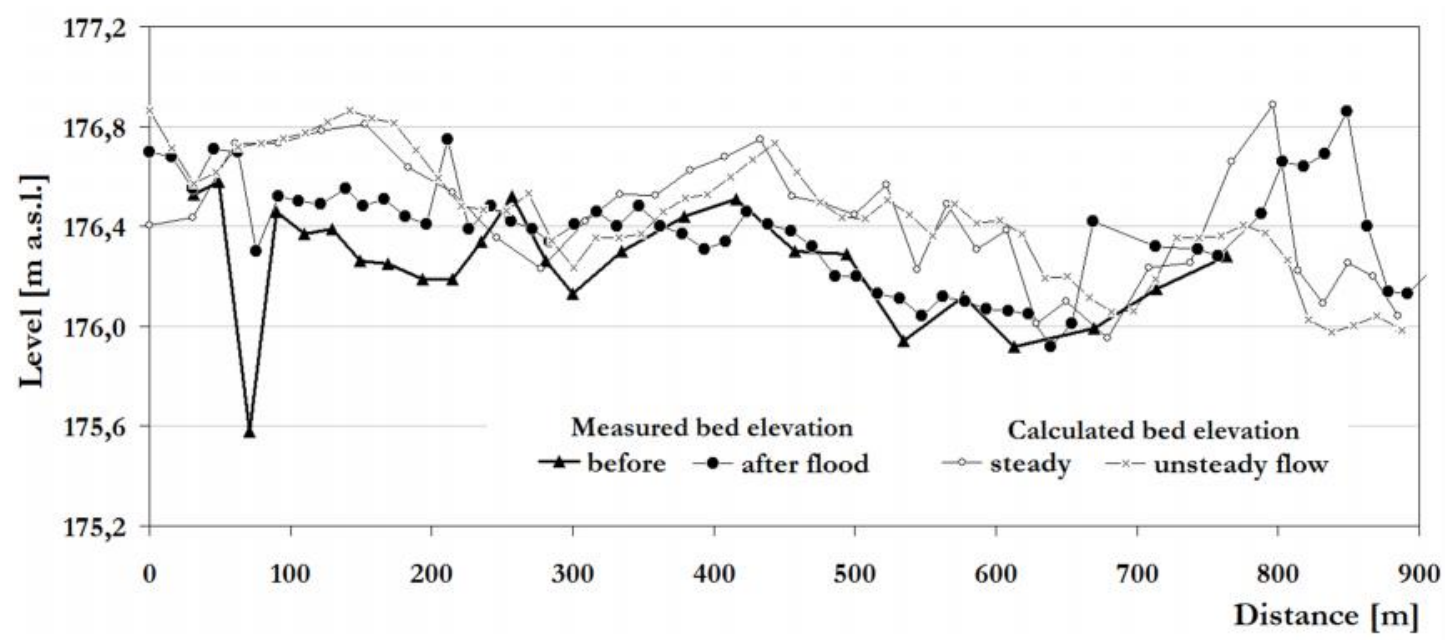

Figure 19. Measured and simulated bed elevations for a section of the Raba River after summer flood 2005

Fig. 19 presents longitudinal profile of the bed elevations along the section of the Raba River, both measured (initial and final) and calculated, for steady and unsteady flow conditions.

At the beginning of the described here reach of the Raba River, the strong erosion process takes place. When finer fractions are washed away from the bed material, the percentage of coarser fractions increases. The bed material composition for the fraction $\mathrm{d}>0.006 \mathrm{~m}$ (size class 7 ) is plotted in Fig. 20 during the flood event. The initial bed material composition for size class $d>$ $0.006 \mathrm{~m}$ equals $35 \%$. For the simulation with $\mathrm{Q}=218.5 \mathrm{~m}^{3} \cdot \mathrm{s}^{-1}$, with backwater effect for unsteady conditions at the beginning of the section of the Raba River the amount of size class 7 increases to about $50-60 \%$ which might be treated as calibration state of model as well as at the end of the computational domain. Formation of the river bed forms starts from $L=150 \mathrm{~m}$ and is observed along a distance of about $600 \mathrm{~m}$.

When the water flow increasing $(t=24 \mathrm{~h})$ starts bedload transport upstream the reach, smaller particles are transported downstream so the grain size composition is changing. It is visible in the Fig. 20 for the time $36 \mathrm{~h}$ - amount of biggest size class increase. When the upper layer is removed the total transport occurs so along the almost all research reach the composition for size class $d>$ 0.006 equals $38-45 \%$. Mass transport lasts until $t=60 \mathrm{~h}$ which means during flood peak. $A$ deposition starts around $t=72 \mathrm{~h}$ when grain size composition for the biggest fraction is changing along the research reach. These phenomena is clear visible for $t=84 \mathrm{~h}$ when composition for fraction $d>0.006 \mathrm{~m}$ is changing from $60 \%$ to $23 \%$ and next from $23 \%$ to $50 \%$ and again in the next cross-sections. Those changes happened at the end of flood event when discharge, water depth, flow velocity and WSL slope is decreasing. 


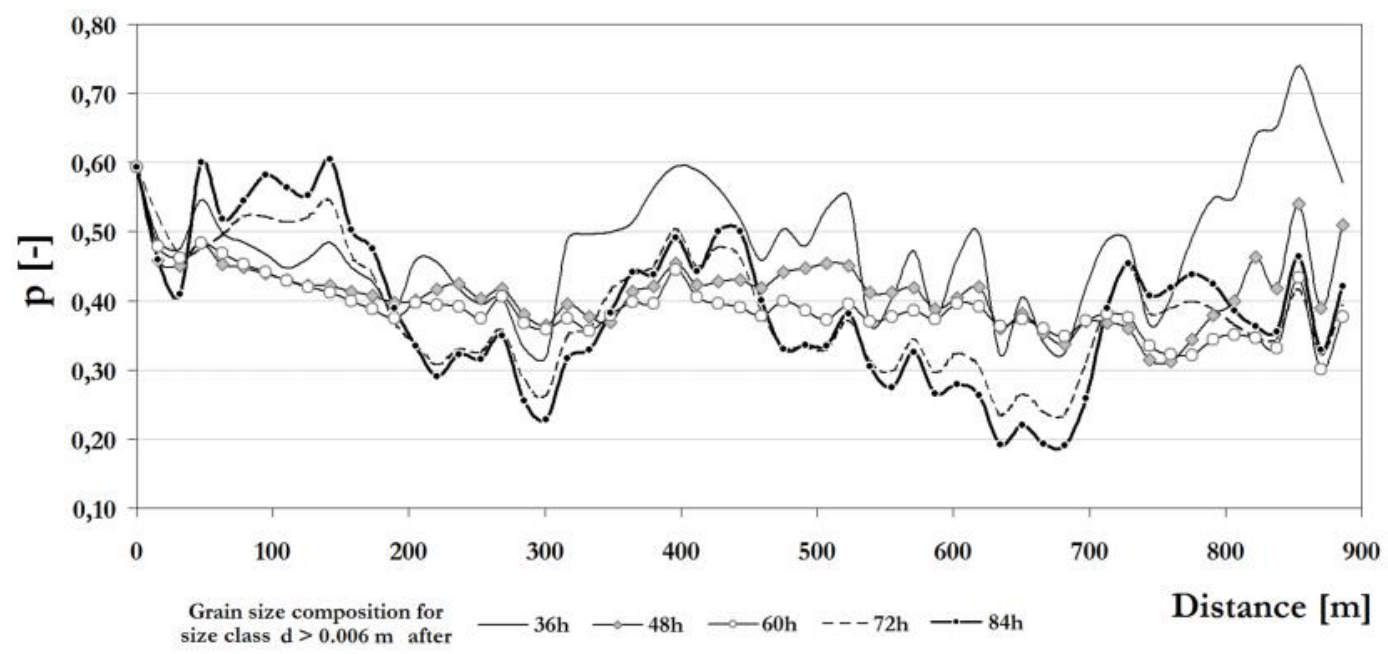

Figure 20. Calculated bed material composition for size class $d>0.006 \mathrm{~m}$ for a section of the Raba River

When the deposition takes place, the bed material composition for size class $d>0.006$ varied along research reach and makes evidence of river bed forms movement. At the end of the research reach, which is close to convergence point the Raba and the Vistula Rivers, the river mouth bed forms starts to develop what is confirmed parallel in bedload calculations as well as in real morphological changes of the riverbed what was surveyed in field.

\section{Conclusions}

The following conclusions can be drawn from the analysis of the data:

1. During the field campaign at the Raba River under the range of low outlet discharges which where up to $Q=3.9 \mathrm{~m}^{3} \cdot \mathrm{s}^{-1}$ only sand and very fine sand-gravel bed forms of $1 \mathrm{~mm}<\mathrm{d}_{50}<2.4 \mathrm{~mm}$, of heights $(\mathrm{H})$ up to tens millimeters can develop and move, whereas other existing sand-gravel features were preserved, sitting on the armored bed. When the discharge has grown up to $Q=$ $11.4 \mathrm{~m}^{3} \cdot \mathrm{s}^{-1}$ the sand-gravel dunes start to develop with $2.4 \mathrm{~mm}<\mathrm{d}_{50}<11 \mathrm{~mm}$. The movement of sediment along such features is under such discharges very low and mostly the crests are set in motion first.

2. The relation between height $(H)$ and length $(L)$ of the Raba River bed forms describes the relation: $H=0.05 L 0.35\left(r^{2}=0.47 ; F 0.05(1 ; 55)=3.95 ; \alpha=0.05 ; n=57\right)$. The Raba's bed forms are much shorter and smaller then the features measured at the bed of larger rivers (e.g. the Rhine). They are mostly below the limitation given by Flemming [1998]. The Raba bed forms are steeper and flatter then the classical dunes described by Allen [1968]. Also they are flatter then the features from bigger rivers (e.g. the Rhine). Their $H / L$ index is: $H / L=0.0518 L 0.622\left(r^{2}=0.71\right.$; F0.05 $(1 ; 51)=7.24 ; \alpha=0.05 ; n=52)$.

3. Calculated directly from field measurements of shear stresses which were observed and responsible for the Raba dunes formation were from $\tau=0.115\left(\mathrm{~N} \cdot \mathrm{m}^{-2}\right)$ to $\tau=1.59\left(\mathrm{~N} \cdot \mathrm{m}^{-2}\right)$ whereas Shields parameter was between 0.0044 and 0.0294 . For such hydraulic conditions for grains d50 
$>2 \mathrm{~mm}$ and still for Shields shear stresses $<0.025$ it is possible to expect sand-gravel dunes formed at the river bed.

4. After reaching the bankfull stage in August 2005 the Raba outlet thalweg was shifted around $50 \mathrm{~m}$, but the meander-like system was still preserved. All the dunes were swept away. The same results come from the model CCHE2D simulations used in the study when along the research reach of the Raba River main stream flows alternately along left and right banks. Calculated shear stresses with the CCHE2D model with unsteady conditions for the flood $Q=218.5 \mathrm{~m} 3 \cdot \mathrm{s}-1$ reached up to $\tau=19.74 \mathrm{~N} \cdot \mathrm{m}^{-2}$. For low discharges, which were near to minimal annual flows, those values of shear stresses varied from $\tau=0.4 \mathrm{~N} \cdot \mathrm{m}^{-2}$ to $\tau=4.1 \mathrm{~N} \cdot \mathrm{m}^{-2}$. The critical shear stresses along the research reach of the Raba River change from $\tau c r=1.1 \mathrm{~N} \cdot \mathrm{m}-2$ to $\tau_{\mathrm{cr}}=6.9 \mathrm{~N} \cdot \mathrm{m}^{-2}$. Even for low discharges local critical conditions of bedload transport are exceeded so bedload transport occur here almost all over the year. Under those hydrodynamic conditions, formation of river forms is much easier despite riverbed material consisting coarse material.

5. During the 2005 August flood peak bedload transport intensity was on average $q b=0.30 \mathrm{~kg} \cdot \mathrm{s}^{-}$ ${ }^{1} \cdot \mathrm{m}^{-1}$, (max $\mathrm{qb}=0.51 \mathrm{~kg} \cdot \mathrm{s}^{-1} \cdot \mathrm{m}^{-1}$ ) for unsteady conditions. Those values are the same as calculated for steady conditions.

6. When modeling the flood event conditions with CCHE2D for high discharges a mass transport was reported. A deposition starts around $t=72 \mathrm{~h}$ when discharge, water depth, flow velocity are decreasing. The grain size composition for the biggest fraction is changing along the research reach.

7. The results of the morphological modeling of the riverbed configuration confirm the real morphological trends for forming the riverbed structure. It is happening especially in places where within the modeling results one can notice the reaches with the tendency for the sediment deposition and erosion and at the same time, during the field survey in those places, one can notice a tendency for river forms developing.

\section{Acknowledgements}

The Authors would like to thank The University of Mississippi, National Center for Computational Hydroscience and Engineering (NCCHE) for allowing to use the CCHE2D model. Also the British Council in Warsaw as well as State Committee for Scientific Research (KBN) Poland are thanked for financial support without which the investigations would not be possible.

\section{References}

Allen J.R.L. 1968. Current Ripples. Amsterdam, North Holland, 433 p.

Allen J.R.L. 1984. Sedimentary Structures: Their Character and Physical Basis. Amsterdam, Elsevier, 539.

Ashley G.M. 1990. Classification of large-scale subaqueous bedforms: a new look at an old problem, J. of Sedimentary Petrology, 60, 160-172.

Bergeron N.E. and A.D. Abrahams. 1992. Estimating shear velocity and roughness length from velocity profiles. Water Resources Research, 28, 8, 2155-2158. 
Best J. 1996. The fluid dynamics of small-scale alluvial bedforms. In Carling P.A. and Dawson M.D. (eds.) Advances in Fluvial Dynamics and Stratigraphy, Chichester, U.K., Wiley, 67-125.

Bridge J.S. 1993. The interaction between channel geometry, water flow, sediment transport and depositin in braided rivers. In Best J.L. and Bristow C.S. (eds. ), Braided rivers, Geol. Soc. London, Spec. Publ. 75, 13-71.

Carling P.A. 1999. Subaqueus gravel dunes. J. of Sediment Research, 69, 3, p. 534-545.

Carling P., and J. Crompton 1988. Freez sampler - user manual. Freshwater Biological association. The Ferry House, Ambleside, Cumbria, UK.

Carling P.A., E. Gölz, H.G. Orr and A. Radecki-Pawlik. 2000. The morphodynamics of fluvial sand dunes in the River Rhine near Mainz, Germany. I. Sedimentology and morphology. Sedimentology, 47, 227-252.

Carling P.A., A. Radecki-Pawlik, J.J. Williams, B. Rumble, L. Meshkova, P. Bell and R.Breakspear. 2005. The morphodynamics and internal structure of intertidal fine-gravel dunes: Hill Flats, Severn Estuary, UK. Sedimentary Geology, Elsevier, 21.

Church M.A., J.F. McLean and J.F. Wolcot. 1987. River Bed Gravels: Sampling and Analysis In Sediment Transport in Gravel-bed Rivers. In C.R. Thorne (eds.) John Wiley and Sons, London, 43-87.

Dietrich W., J. Kirchner, H. Ikeda and F. Iseya. 1989. Sediment supply and the development of the coarse surface layer in gravel-bedded rivers. Nature, 340, 215-217.

Dinehart R.L. 1989. Dune migration in a sleep, coarse-bedded stream. Water Resources Research, 25, 911-923.

Flemming B.W. 1988. Zur klassifikation subaquatischer stomungsiransversaler Transport-korper. Bochumer Geologische und Geotechnische Arbeiten, 29, p. 44-47.

Galay V.J. 1967. Observed forms of bed roughness in an unstable gravel river. International, In Proc. Assoc. for Hydraulic Research. 12th Congress., 85-94.

Gomez B., R. Naff and D. Humbbell. 1989. Temporal variations in bed load transport rates associated with the migrations of bedforms. Earth Surface Processes and Landforms, 14, 135156.

IMGW. 2005. Institute of Meteorology and Water Management, Poland, www.imgw.pl.

Iseya S. and H. Ikeda. 1987. Pulsation in bedload transport rates induced by a longitudinal sediment sorting: a flume study of sand and gravel mixtures: Geografiska Annaler, 69A, 1527.

Jarrett R. 1990. Wading measurements of velocity profiles. Geomorphology, 4, 43-247.

Jia Y., S.S.Y. Wang, 2001a. CHE2D: Two-dimensional Hydrodynamic and Sediment Transport Model For Unsteady Open Channel Flows Over Loose Bed, Rep. NCCHE, The University of Mississippi. USA.

Jia Y., S.S.Y. Wang. 2001b. CHE2D: Verification and validation tests documentation, Rep. NCCHE, The University of Mississippi. USA.

Krzanowski S. 1972. The spatial changes of the average discharge, (in Polish). Ph.D. thesis. Agricultural University of Krakow. 254.

Książek L. and A. Radecki-Pawlik. 2008. Modeling of hydrodynamics conditions within the outlet of a sand-gravel upland river - the Raba River, Polish Carpathians. In Altinakar, Kokpinar, 
Aydin, Cokgor \& Kirkgoz (eds.) Proc. Int. Conf. on Fluvial Hydraulics, River Flow 2008, 2. 13991406.

Kuhnle R. 1986. Experimental studies of heavy-mineral transpiration - segregation. and deposition in gravel-bed streams. Ph.D, thesis. Cambridge. Massachusetts. Massachusetts Institute of Technology. 209.

Michalik A. 1990. Bed-load transport investigations in some Polish Carpathians rivers, (in Polish). Zesz. Nauk. AR Krakow seria Rozpr. Hab., 138, 115.

Michalik A., W. Bartnik, T. Król, L. Książek, A. Niziołek and A. Radecki-Pawlik. 1996. Badania skladu granulometrycznego rumowiska $w$ rzekach górskich metodą zamrażania próby in situ, (in Polish), Zesz. Nauk. AR Krakow, 306, 79-92. 1996.

Meirovich L., J.B. Laronne and I. Reid. 1998. The variation of water-surface slope and its significance for bedload transport during floods in gravel-bed streams, J. of Hydraulic Research, 36, 2, 147-157.

Moriasi D.N., J.G. Arnold, M.W. Van Liew, R.L. Bingner, R.D. Harmel and T.L. Veith. 2007. Model evaluation guidelines for systematic quantification of accuracy in watershed simulations. Amer. Soc. of Agricultural and Biological Engineers, 50(3):885-900.

Nash J.E., and J.V. Sutcliffe. .1970. River flow forecasting through conceptual models part I -- A discussion of principles, J. of Hydrology, 10, 3, 282-290, doi: 10.1016/0022-1694(70)90255-6.

Przedwojski B., R. Błażejewski, K.W. Pilarczyk. 1995. River training techniques. Balkema, Rotterdam, Brookfield, 287.

Radecki-Pawlik A., P. Carling, E. Słowik-Opoka, L. Książek and R. Breakspeare. 2006. Field investigations of sand-gravel bed forms within the Raba river, Poland. In R.M.L. Ferreira, E.C.T.L. Alves, J.G.A.B. Leal \& A.H. Cardoso (eds.), Proc. River Flow 2006, Water and Earth Science, Taylor \& Francis, London, 1, 979-985.

Słowik-Opoka E. 2006. The hydraulics conditions of sand-gravel river bed formation, (in Polish), PhD thesis. Agricultural University, Krakow.

Whiting P.J. 1996. Sediment sorting over bed topography. In P.A. Carling and M.R. Dawson (eds.) Advances in Fluvial Dynamics and Stratygraphy. Chichester, UK, Wiley, 204-228.

Whiting P., W. Dietrich, L. Leopold, T. Drake and R. Shreye. 1988. Bedload sheets in heterogeneous sediment. Geology, 16. 105-108.

Wijbenga J.H. 1990. Flow resistance and bed-form dimensions for varying flow conditions. Delft Hydraulics. Part 1-4, Toegepast Onderzoek Waterstaat, A58.

Wyzga B. 1992. Evolution of the fluvial system of the middle and lower Raba in the last 200 years, (in Polish). Polish Academy of Science IGiPZ. Ph.D. thesis. Warszawa. 92.

Wu W. 2001. CCHE2D Sediment Transport Model, Rep. National Center for Computational Hydroscience and Engineering, The University of Mississippi.

Wu W., S.S.Y. Wang and Y. Jia. 2000. Nonuniform Sediment Transport in Alluvial Rivers, J. of Hydr. Research, IAHR, Vol. 38 (6).

Yalin M. 1964. Geometrical properties of sand waves. In. Proc. Am. Soc. Civ. Eng., Raport 90, 119.

Xu Y.C., Y. Jia and S.S.Y. Wang. 2001. Applications of a depth-integrated two dimensional numerical model to the Lauffen reservoir on the Necker River. In Proc. XXIX IAHR Congress. Hydraulics of Rivers, Water and Machinery, II, 134-139.

Zhang Y. and Y. Jia. 2005. CCHE2D Mesh Generator, Rep. NCCHE, University of Mississippi. 